\title{
Effect of Mn on the Performance and Mechanism of Catalysts for the Synthesis of $(\mathrm{Ce}, \mathrm{La}) \mathrm{CO}_{3} \mathrm{~F}$
}

\author{
Zedong Cheng', ${ }^{1} \mathrm{Li}^{1,2}$, Liming Hou ${ }^{3}$, Kunling Jiao1,3, Wenfei Wu${ }^{1.3 *}$ \\ ${ }^{1}$ Department of Energy and Environment, Inner Mongolia University of Science and Technology, Baotou, China \\ ${ }^{2}$ Department of Environmental Science and Engineering, North China Electric Power University, Baoding, China \\ ${ }^{3}$ Key Laboratory of Efficient and Clean Combustion, Inner Mongolia Autonomous Region, Baotou, China \\ Email: *wwf@imust.edu.cn
}

How to cite this paper: Cheng, Z.D., Li, N., Hou, L.M., Jiao, K.L. and Wu, W.F. (2021) Effect of Mn on the Performance and Mechanism of Catalysts for the Synthesis of $(\mathrm{Ce}, \mathrm{La}) \mathrm{CO}_{3} \mathrm{~F}$. Journal of Power and Energy Engineering, 9, 1-32. https://doi.org/10.4236/jpee.2021.911001

Received: August 17, 2021

Accepted: November 14, 2021

Published: November 17, 2021

Copyright $\odot 2021$ by author(s) and Scientific Research Publishing Inc. This work is licensed under the Creative Commons Attribution International License (CC BY 4.0).

http://creativecommons.org/licenses/by/4.0/

\begin{abstract}
In accordance with the cerium-lanthanum ratio of fluorocerium ores in the mineralogy of the Baiyun Ebo process, the (Ce, $\mathrm{La}) \mathrm{CO}_{3} \mathrm{~F}$ grains were synthesised by hydrothermal method using pure material to simulate bastnaesite minerals, and used as $\mathrm{NH}_{3}$-SCR denitrification catalysts. The activity results showed that the synthetic $(\mathrm{Ce}, \mathrm{La}) \mathrm{CO}_{3} \mathrm{~F}$ was roasted at $500^{\circ} \mathrm{C}$, and the $\mathrm{NOx}$ conversion was $27 \%$ at $200^{\circ} \mathrm{C}$. The $\mathrm{NH}_{3}-\mathrm{SCR}$ catalytic activity of the synthesised $(\mathrm{Ce}, \mathrm{La}) \mathrm{CO}_{3} \mathrm{~F}$ was improved by loaded transition metal $\mathrm{Mn}$. The best catalyst was found to be produced by impregnating $(\mathrm{Ce}, \mathrm{La}) \mathrm{CO}_{3} \mathrm{~F}$ with 1 $\mathrm{mol} / \mathrm{L}$ manganese nitrate solution, with a $\mathrm{NOx}$ conversion of $80 \%$ at $250^{\circ} \mathrm{C}$. The loading of $\mathrm{Mn}$ resulted in the appearance of numerous well-dispersed $\mathrm{MnOx}$ species on the catalyst surface, the dispersion of $\mathrm{Ce}_{7} \mathrm{O}_{12}$ species was also greatly enhanced, and the reduction in grain size indicated that $\mathrm{Mn}^{\mathrm{nt}}$ entered into the $(\mathrm{Ce}, \mathrm{La}) \mathrm{CO}_{3} \mathrm{~F}$ lattice causing lattice shrinkage. The number of acidic sites on the catalyst surface and the redox capacity were enhanced. The amount of $\mathrm{Ce}^{3+}$ in the catalyst was also enhanced by the introduction of $\mathrm{Mn}^{\mathrm{n}+}$, but the proportion of adsorbed oxygen decreased, which indicated that the introduction of $\mathrm{Mn}^{\mathrm{n}+}$ was detrimental to the increase in the proportion of adsorbed oxygen. The reaction mechanisms of the $(\mathrm{Ce}, \mathrm{La}) \mathrm{CO}_{3} \mathrm{~F}$ and $\mathrm{Mn} /(\mathrm{Ce}, \mathrm{La}) \mathrm{CO}_{3} \mathrm{~F}$ catalysts were investigated by in-situ Fourier transform infrared spectroscopy (FTIR). The results showed that catalysts followed the $\mathrm{E}-\mathrm{R}$ and L-H mechanisms. When loaded with $\mathrm{Mn}$, the main reactive species in the $\mathrm{L}-\mathrm{H}$ mechanism were the $\mathrm{NH}_{4}^{+}$(ad) species on the Brønsted acidic site and the $\mathrm{O}-\mathrm{Ce}^{3+}-\mathrm{O}-\mathrm{NO}, \mathrm{O}-\mathrm{Mn}^{3+}-\mathrm{O}-\mathrm{NO}$ species. The main reactive species for the E-R mechanism were $\mathrm{NH}_{3} / \mathrm{NH}_{4}^{+}$(ad) species and $\mathrm{NO}$. The $\mathrm{NH}_{4}^{+}$ (ad) species on the Brønsted acidic sites act as the main reactive NH3 (g) ad-
\end{abstract}


sorbing species, bonded to the $\mathrm{Ce}^{4+}$ in the carrier $(\mathrm{Ce}, \mathrm{La}) \mathrm{CO}_{3} \mathrm{~F}$ to participate in the acid cycle reaction. The introduction of $\mathrm{Mn}^{\mathrm{n}+}$ increases the number of Brønsted acidic sites on the catalyst surface, and acts as an adsorption site for NO, to react with NO to generate more monodentate nitrate species, to participate in the redox cycle reactions. The above results indicated that $\mathrm{Mn}^{\mathrm{n}+}$ and $(\mathrm{Ce}, \mathrm{La}) \mathrm{CO}_{3} \mathrm{~F}$ have a good mutual promotion effect, which makes the loaded catalyst have excellent performance, which provides a theoretical basis for the high value utilization of bastnaesite.

\section{Keywords}

Synthesis of (Ce,La) $\mathrm{CO}_{3} \mathrm{~F}$, Load, Denitrification Performance, Reaction Mechanism

\section{Introduction}

In recent years, domestic coal consumption has tended to increase and the air pollution problem caused by the coal combustion process has become increasingly serious, with coal-fired power plants representing $60 \%$ of the overall emissions from stationary sources. The use of coal, diesel and petrol to produce NOx can lead to a range of environmental problems, so NOx removal and reduction is imperative. SCR technology (Selective Catalytic Reduction) is now favoured by many researchers in the field of denitrification. The traditional $\mathrm{V}_{2} \mathrm{O}_{5}-\mathrm{WO}_{3}\left(\mathrm{MoO}_{3}\right) / \mathrm{TiO}_{2}$ catalyst has not yet been solved due to its toxicity and narrow denitration temperature window, which has led to the research of new catalysts. Mineral catalysts have received increased attention from scholars due to their non-toxicity and wide range of elements.

The main rare-earth minerals in Baiyun Ebo rare-earth concentrates are bastnaesite, and the main rare-earth elements in rare-earth concentrates are $\mathrm{Ce}, \mathrm{La}$, $\mathrm{Nd}$ and $\operatorname{Pr}$ [1], of which cerium has a very efficient and promising future as a mineral catalytic material. However, the composition of rare earth concentrates is complex and the available characterisation tools have no way of determining the specific reaction changes of a multi-phase component catalyst. Exploring its specific reaction mechanism as a catalyst is also a blind spot that is difficult to break through, so we need to look at the mineral phases that play a catalytic role in the concentrate on a case-by-case basis and explore their denitrification mechanisms. As the main mineral phase in rare earth concentrates, the study of bastnaesite is necessary. The present technical means cannot extract the more pure bastnaesite, but there are many scholars who use the pure material to synthesise the mineral to study its properties. Huang Shunhua et al. [2] synthesised bastnaesite by hydrothermal method. Experimental results showed that from room temperature to $400^{\circ} \mathrm{C}$, atmospheric pressure to $100 \mathrm{MPa}$, the solution $\mathrm{pH}$ from 6.7 to 11.0 range as long as the necessary substances to form the mineral can be synthesized bastnaesite. The molecular formula of bastnaesite is 
(Ce, $\mathrm{La}) \mathrm{CO}_{3} \mathrm{~F}$ according to the mineralogy of the Baiyun Ebo rare earth concentrate process, and the $(\mathrm{Ce}, \mathrm{La}) \mathrm{CO}_{3} \mathrm{~F}$ crystals were prepared by the hydrothermal method of analytical purity.

The roasting of $(\mathrm{Ce}, \mathrm{La}) \mathrm{CO}_{3} \mathrm{~F}$ produced $\mathrm{Ce}_{7} \mathrm{O}_{12}$ species, which had poor performance as denitrification catalysts due to its good crystallinity, so the catalytic performance of $(\mathrm{Ce}, \mathrm{La}) \mathrm{CO}_{3} \mathrm{~F}$ was promoted by introducing the transition metal $\mathrm{Mn}$ to improve the dispersion of $\mathrm{Ce}_{7} \mathrm{O}_{12}$ species, as well as generating new active components. Cerium-based catalysts have excellent low-temperature catalytic performance, and many researchers have used $\mathrm{CeO}_{2}$ as a carrier to improve the performance of $\mathrm{NH}_{3}$-SCR. Solid oxide catalysts are sourced for due to their advantages ranging from low cost, recoverability and reusability, environmental benign-ness, thermal stability and high quality product generation [3]. Yao Xiaojiang [4] prepared a series of $\mathrm{MnOx} / \mathrm{CeO}_{2}$ catalysts by adjusting the solvents (deionised water, anhydrous ethanol, acetic acid, oxalic acid solution). The $\mathrm{MnOx} / \mathrm{CeO}_{2}$ catalysts prepared with oxalic acid solution as the solvent showed over $80 \% \mathrm{NO}$ conversion in the range of $100^{\circ} \mathrm{C}-250^{\circ} \mathrm{C}$, and good low temperature sulphur and water resistance, probably because the solvent oxalic acid enhanced the electronic interaction between $\mathrm{MnOx}$ and $\mathrm{CeO}_{2}$ and increased the oxygen vacancies in the carrier $\mathrm{CeO}_{2}$, which can promote the decomposition of NO species. Therefore, this paper is used to improve the catalytic performance of $(\mathrm{Ce}, \mathrm{La}) \mathrm{CO}_{3} \mathrm{~F}$ by loaded $\mathrm{Mn}$, and to study its $\mathrm{NH}_{3}$-SCR physicochemical properties and reaction mechanism by characterization and in-situ infrared, to clarify the specific reaction mechanism within bastnaesite, and to provide theoretical guidance for the reaction performance and mechanism of rare earth mineral catalysts.

\section{Experimental Methods}

\subsection{Experimental Materials}

Reagents used in the experiments, $\mathrm{Ce}\left(\mathrm{NO}_{3}\right)_{3} \cdot 6 \mathrm{H}_{2} \mathrm{O}$ (mass fraction), analytical purity, Tianjin Comio Chemical Reagent Co. $\mathrm{La}\left(\mathrm{NO}_{3}\right)_{3} \cdot 6 \mathrm{H}_{2} \mathrm{O}$ (mass fraction), analytical purity, Tianjin Comio Chemical Reagent Co. $\mathrm{NaHCO}_{3}$, analytical purity, Tianjin Windship Chemical Reagent Technology Co. NaF, analytical purity, Tianjin Windship Chemical Reagent Technology Co. $\mathrm{Mn}\left(\mathrm{NO}_{3}\right)_{2}$, analytical purity, Shanghai Zhangyun Chemical Co.

\subsection{Preparation of Catalyst}

The synthesis of (Ce, $\mathrm{La}) \mathrm{CO}_{3} \mathrm{~F}$ was carried out by hydrothermal method. A certain amount of $\mathrm{Ce}\left(\mathrm{NO}_{3}\right)_{3} \cdot 6 \mathrm{H}_{2} \mathrm{O}, \mathrm{La}\left(\mathrm{NO}_{3}\right)_{3} \cdot 6 \mathrm{H}_{2} \mathrm{O}, \mathrm{NaF}, \mathrm{NaHCO}_{3}$ was placed in $100 \mathrm{ml}$ of PTFE liner at room temperature. Then $80 \mathrm{ml}$ of distilled water was poured into the PTFE liner with constant stirring, and the PTFE liner was placed into an autoclave under atmospheric pressure and $120^{\circ} \mathrm{C}$ with stirring and heating for $2 \mathrm{~h}$ for hydrothermal reaction. After cooling, the mixture was filtered and dried at $80^{\circ} \mathrm{C}$ to obtain synthetic $(\mathrm{Ce}, \mathrm{La}) \mathrm{CO}_{3} \mathrm{~F}$. After cooling, the mixture was 
filtered and dried at $80^{\circ} \mathrm{C}$ to obtain synthetic $(\mathrm{Ce}, \mathrm{La}) \mathrm{CO}_{3} \mathrm{~F} . \mathrm{Mn}\left(\mathrm{NO}_{3}\right)_{2}$ was dissolved in deionised water using the impregnation method and continuously stirred to form manganese nitrate solutions at concentrations of $0.2 \mathrm{~mol} / \mathrm{L}, 0.4 \mathrm{~mol} / \mathrm{L}, 0.6$ $\mathrm{mol} / \mathrm{L}, 0.8 \mathrm{~mol} / \mathrm{L}$ and $1.0 \mathrm{~mol} / \mathrm{L}$, respectively. The synthetic $(\mathrm{Ce}, \mathrm{La}) \mathrm{CO}_{3} \mathrm{~F}$ was used as a carrier and poured into different concentrations of $\mathrm{Mn}\left(\mathrm{NO}_{3}\right)_{2}$ solution, sonicated for $2 \mathrm{~h}$, left overnight, filtered and dried the suspension, and then roasted in a muffle furnace at $500^{\circ} \mathrm{C}$ for $2 \mathrm{~h}$. The solid material obtained was the $\mathrm{Mn} /(\mathrm{Ce}, \mathrm{La}) \mathrm{CO}_{3} \mathrm{~F}$ catalytic material.

\subsection{Experimental Procedure}

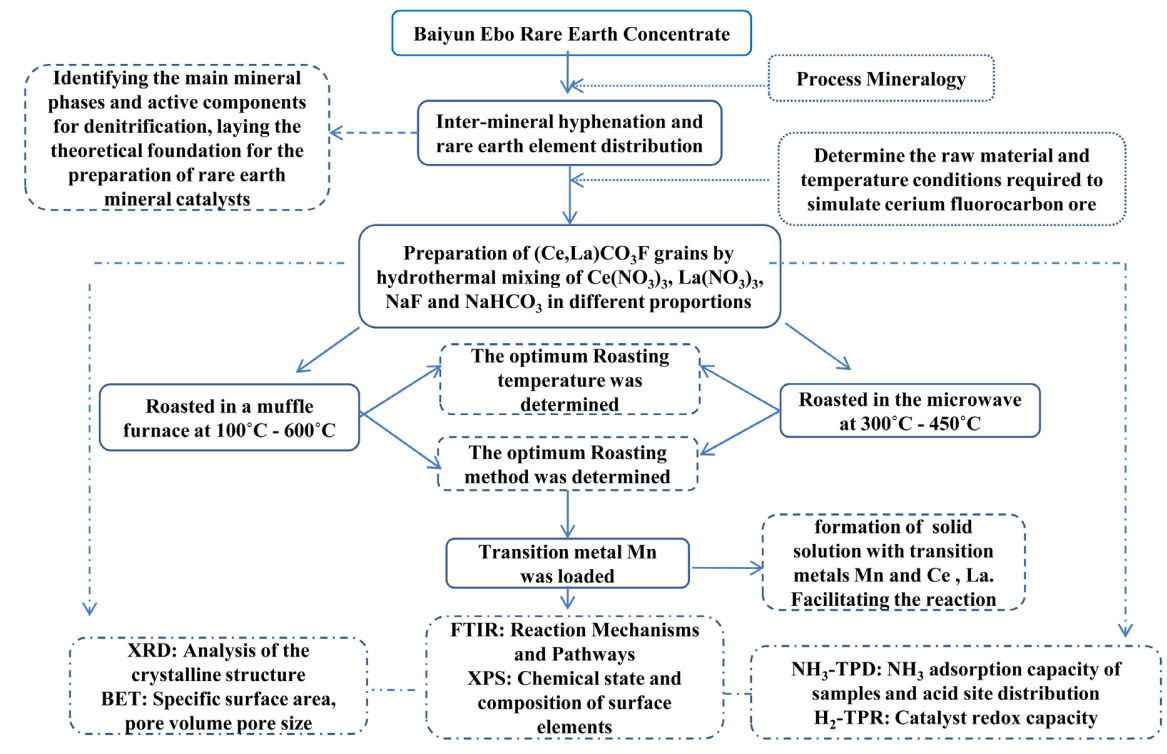

\subsection{Testing of Catalytic Performance}

The experiments were carried out in a reaction apparatus with quartz tubes for testing the activity of the catalyst $\mathrm{NH}_{3}$-SCR. The reaction apparatus consists of a gas mixing tank-flow meter, standpipe furnace, quartz tube, Fourier infrared spectroscopy flue gas analyser and computer data acquisition system. The standpipe furnace was heated by a silicon-molybdenum rod model 1800 with a rated temperature of $1600^{\circ} \mathrm{C}$ and an internal diameter of $20 \mathrm{~mm}$ and a length of $1.2 \mathrm{~m}$ from Nanjing Boynton Instrument Technology Co. The Fourier infrared spectroscopy (FTIR) flue gas analyser and data acquisition system were manufactured in Finland, and the model number was GASMET-DX4000. The simulated gas components were as follows: $\mathrm{NH}_{3} 500 \mathrm{ppm}$, NO $500 \mathrm{ppm}, \mathrm{O}_{2}$ at a volume fraction of $6 \%$ of the total, $\mathrm{N}_{2}$ as the equilibrium gas, a total gas flow of 100 $\mathrm{ml} / \mathrm{min}$, an air velocity of approximately $8000 \mathrm{~h}^{-1} \cdot \mathrm{g}^{-1}$ and a catalyst dosage of 0.6 $\mathrm{g}$ for each test.

\section{Results and Discussion}

\subsection{Catalytic Performance Tests}

Figure 1 showed the $\mathrm{NOx}$ conversion and $\mathrm{N}_{2}$ selectivity of the $\mathrm{Mn} /(\mathrm{Ce}, \mathrm{La}) \mathrm{CO}_{3} \mathrm{~F}$ 


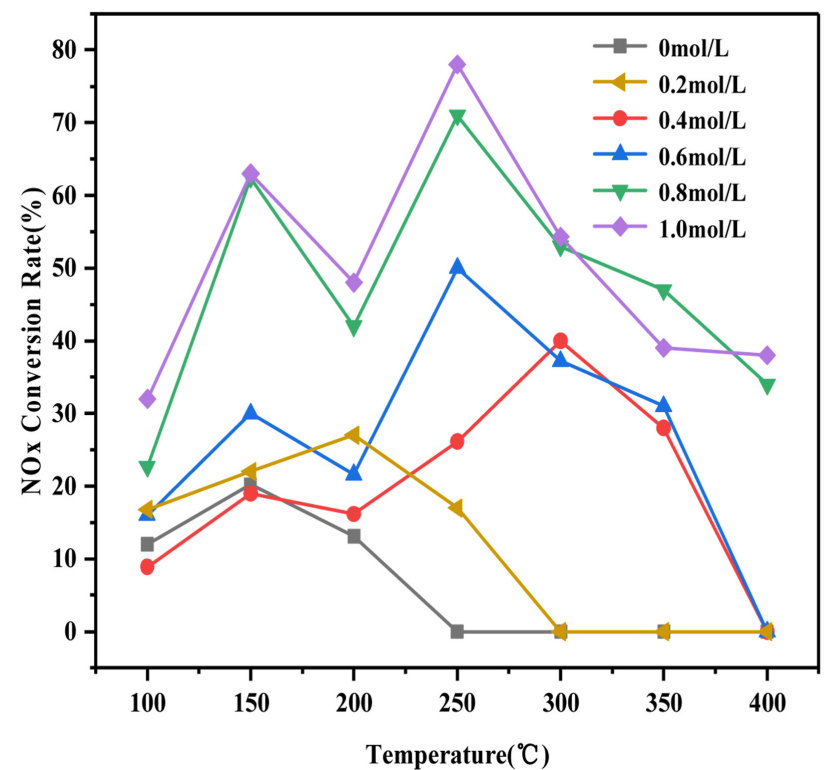

(a)

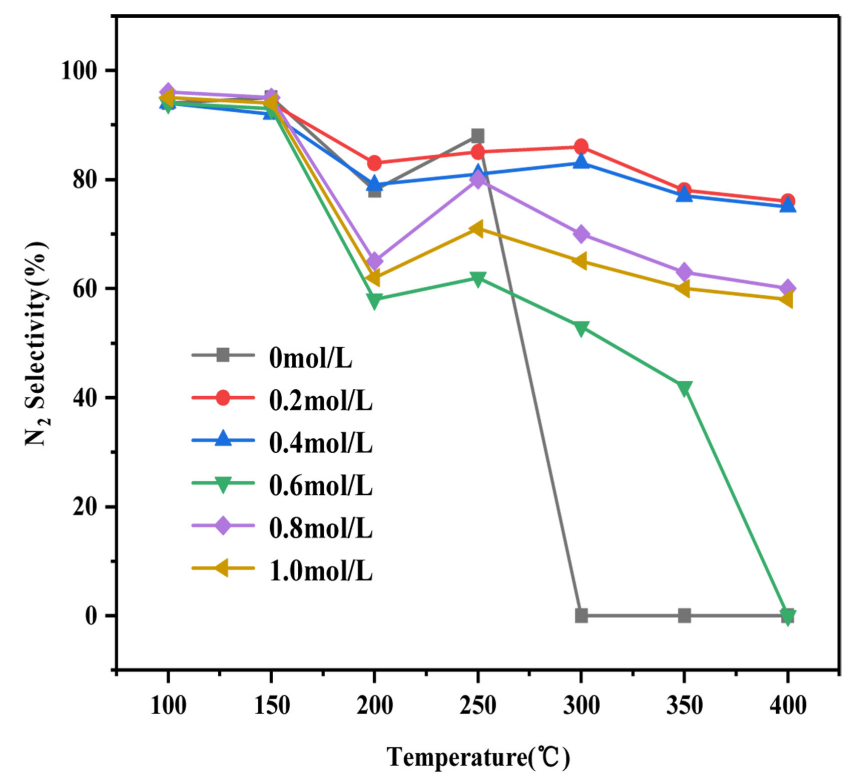

(b)

Figure 1. NOx conversion over catalyst (a) $\mathrm{N}_{2}$ selectivity (b). (Reaction conditions $500 \mathrm{ppm} \mathrm{NO}, 500$ ppm $\mathrm{NH}_{3}, 6 \% \mathrm{O}_{2}, \mathrm{~N}_{2}$ as balance gas).

catalysts obtained with Mn loaded. From the denitrification activity results, it can be seen that the NOx conversion of the $\mathrm{Mn} /(\mathrm{Ce}, \mathrm{La}) \mathrm{CO}_{3} \mathrm{~F}$ catalysts with different loadings all increased with temperature in the temperature range of $100^{\circ} \mathrm{C}$ $150^{\circ} \mathrm{C}$, but as the temperature continued to be increased, the NOx conversion started to decrease at $200^{\circ} \mathrm{C}$ and then increased again at $250^{\circ} \mathrm{C}$ to reach the highest value for the whole catalytic reaction.

The reason for this may be due to the large amount of $\mathrm{NO}$ adsorbed on the catalyst surface in the range of $100^{\circ} \mathrm{C}-150^{\circ} \mathrm{C}$, which reduces the value of NOx, but NOx is not being reacted on the catalyst surface at this point, merely occupied as an active site, and as NO continues to pass through, NO cannot continue to be adsorbed, due to the absence of active sites on the catalyst surface. It is not until $250^{\circ} \mathrm{C}$ that the $\mathrm{NH}_{3}$-SCR reaction on the catalyst surface begins to take place, allowing the catalyst to reach maximum denitrification efficiency. It may also be due to the activation of species by adsorption of $\mathrm{NH}_{3}$ and $\mathrm{NO}$ on the catalyst surface. That is to say, $\mathrm{NH}_{3} / \mathrm{NH}_{4}^{+}$and species such as $\mathrm{NO}_{2}$, nitrate and nitrite are less stable on the catalyst surface and are particularly susceptible to temperature, decomposing at $200^{\circ} \mathrm{C}$, which leads to a decrease in activity. It can be found that when $(\mathrm{Ce}, \mathrm{La}) \mathrm{CO}_{3} \mathrm{~F}$ is impregnated in a $1 \mathrm{~mol} / \mathrm{L}$ solution of $\mathrm{Mn}\left(\mathrm{NO}_{3}\right)_{2}$, the conversion of catalyst NOx can reach $80 \%$ at $250^{\circ} \mathrm{C}$. However, as the temperature continued to increase, the conversion rate also gradually decreased, which may be due to the oxidation of the reducing agent $\mathrm{NH}_{3}$, which resulted in a decrease in the amount of reducing agent, and the oxidation of $\mathrm{NH}_{3}$ at high temperature would release NO, which increased the concentration of NO but decreased the conversion rate. Figure 1 (b) showed the $\mathrm{N}_{2}$ selectivity graphs for the synthesis of $(\mathrm{Ce}, \mathrm{La}) \mathrm{CO}_{3} \mathrm{~F}$ as well as $(\mathrm{Ce}, \mathrm{La}) \mathrm{CO}_{3} \mathrm{~F}$ loaded with $\mathrm{Mn} . \mathrm{N}_{2}$ se- 
lectivity is another important indicator to evaluate denitrification performance. In the $\mathrm{NH}_{3}$-SCR denitrification process, side reactions such as oxidation of ammonia and high temperature decomposition of nitrate and ammonium nitrogen lead to partial production of $\mathrm{N}_{2} \mathrm{O}$, which greatly reduces the $\mathrm{N}_{2}$ selectivity. From Figure 1(b) it can be obtained that when loaded with the transition metal Mn, the $\mathrm{N}_{2}$ selectivity of the catalyst starts to decrease after $150^{\circ} \mathrm{C}$, which is related to the excessive hydrogen capture due to the strong redox ability of $\mathrm{Mn}^{\mathrm{n}+}$.

\subsection{Physical Phase Structure Analysis}

Figure 2 showed XRD diagrams of the synthetic (Ce,La) $\mathrm{CO}_{3} \mathrm{~F}$ catalyst roasted at $200^{\circ} \mathrm{C}-600^{\circ} \mathrm{C}$ in a muffle furnace. As can be seen in Figure 2, at $200^{\circ} \mathrm{C}$ most of the $\mathrm{CeCO}_{3} \mathrm{~F}, \mathrm{LaCO}_{3} \mathrm{~F}$ and $(\mathrm{Ce}, \mathrm{La}) \mathrm{CO}_{3} \mathrm{~F}$ do not decompose, but the degree of crystallinity and dispersion is greatly improved and many of the diffraction peaks are significantly reduced.

At $300^{\circ} \mathrm{C}$ the diffraction peaks of species such as $\mathrm{CeCO}_{3} \mathrm{~F}$ and $\mathrm{LaCO}_{3} \mathrm{~F}$ are further reduced and some decomposition occurs. The decomposition of $\mathrm{CeCO}_{3} \mathrm{~F}$ gave rise to $\mathrm{Ce}_{11} \mathrm{O}_{20}, \mathrm{Ce}_{6} \mathrm{O}_{11}, \mathrm{Ce}_{7} \mathrm{O}_{12}$ and $\mathrm{CeF}_{3}$ species, and the decomposition of $\mathrm{LaCO}_{3} \mathrm{~F}$ gave rise to $\mathrm{LaCO}, \mathrm{La}_{2} \mathrm{O}_{3}$ and $\mathrm{LaF}_{3}$ species, with the $(\mathrm{Ce}, \mathrm{La}) \mathrm{CO}_{3} \mathrm{~F}$ catalyst starting to decompose at $300^{\circ} \mathrm{C}$. At $400^{\circ} \mathrm{C}$, the most active stage of decomposition on the catalyst surface, $\mathrm{CeCO}_{3} \mathrm{~F}$ and $\mathrm{LaCO}_{3} \mathrm{~F}$ species were completely decomposed, with only a few species in amorphous form on the catalyst surface, and a large amount of $\mathrm{CeCO}_{3} \mathrm{~F}$ decomposed into $\mathrm{Ce}_{11} \mathrm{O}_{20}$ and $\mathrm{Ce}_{6} \mathrm{O}_{11}$ species, and $\mathrm{Ce}_{7} \mathrm{O}_{12}$ species increased significantly compared to $300^{\circ} \mathrm{C}$. The main diffraction

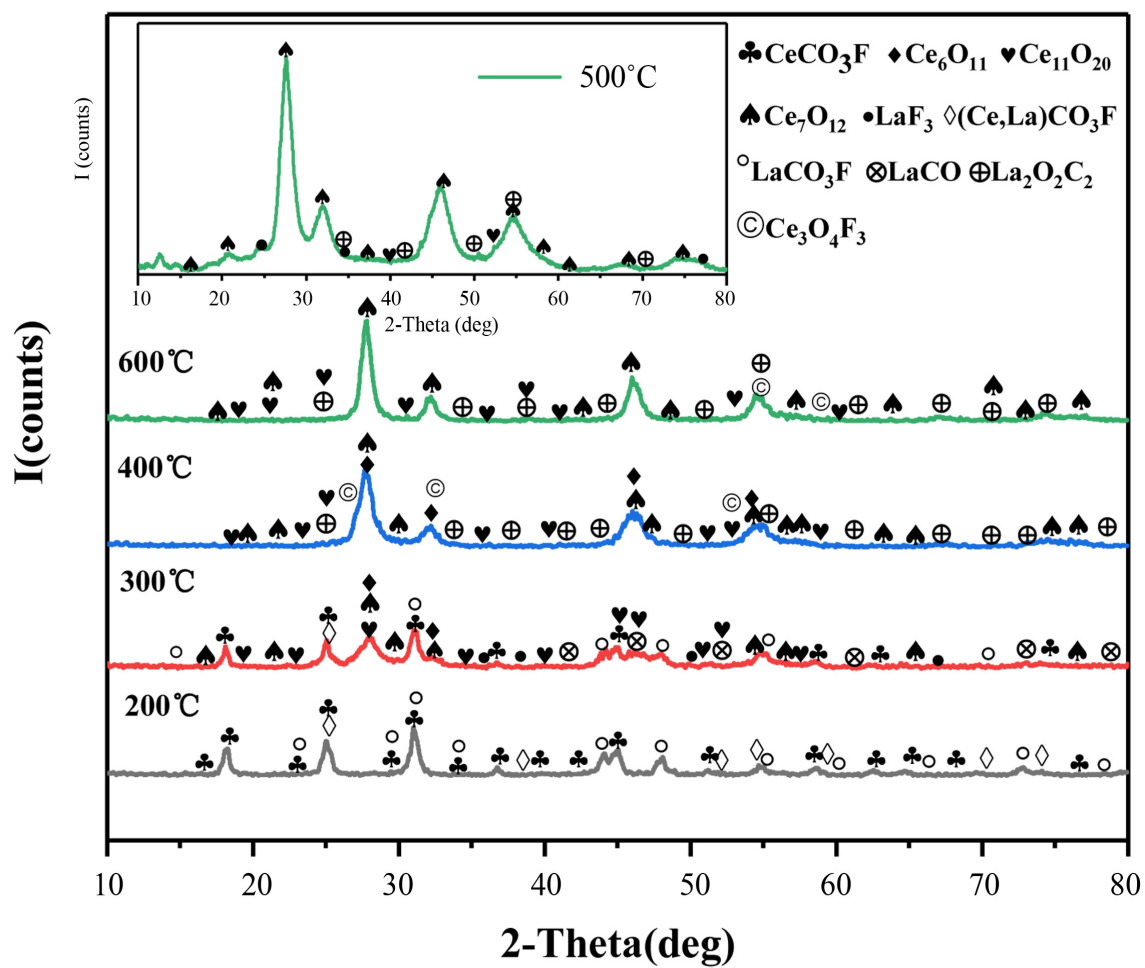

Figure 2. XRD patterns of $(\mathrm{Ce}, \mathrm{La}) \mathrm{CO}_{3} \mathrm{~F}$ after roasting at different temperatures. 
peaks were mostly a composite of $\mathrm{Ce}_{7} \mathrm{O}_{12}$ and $\mathrm{Ce}_{6} \mathrm{O}_{11}$ species, both of which were formed under very similar conditions. The $500^{\circ} \mathrm{C}$ roasting condition is the most stable stage for the catalyst surface species, and the main diffraction peaks of the catalyst are all $\mathrm{Ce}_{7} \mathrm{O}_{12}$ species, while $\mathrm{LaCO}_{3} \mathrm{~F}$ is present as $\mathrm{La}_{2} \mathrm{C}_{2} \mathrm{O}_{2}$, with some $\mathrm{CeF}_{3}$ and $\mathrm{LaF}_{3}$ species also present. Combined with the activity tests at different roasting temperatures, the best denitrification effect was obtained after roasting at $500^{\circ} \mathrm{C}$. Therefore, combined with the XRD pattern at $500^{\circ} \mathrm{C}$, it can be seen that the $\mathrm{Ce}_{7} \mathrm{O}_{12}$ species is the main active component of the reaction, which is more favourable to interact with other substances to promote the reaction than the $\mathrm{Ce}_{11} \mathrm{O}_{20}$ and $\mathrm{Ce}_{6} \mathrm{O}_{11}$ species. At $600^{\circ} \mathrm{C}$, the $\mathrm{Ce}_{7} \mathrm{O}_{12}$ species on the catalyst surface decreased and $\mathrm{Ce}_{11} \mathrm{O}_{20}$ and $\mathrm{Ce}_{6} \mathrm{O}_{11}$ species gradually appeared, so there was a relative decrease in the active component, perhaps due to the change in catalyst structure caused by the high roasting temperature, which was not conducive to the reaction.

Figure 3 showed the XRD patterns of Mn loaded by the over-impregnation method. From Figure 3, it can be seen that the diffraction peaks of $\mathrm{Ce}_{7} \mathrm{O}_{12}$ were dominated on the catalyst surface, accompanied by some $\mathrm{CeO}_{2}$ species produced after roasting, and $\mathrm{CeOF}$ species. The diffraction peaks of $\mathrm{Ce}_{7} \mathrm{O}_{12}$ species on the catalyst surface decreased gradually with increasing loading. Indicated that the addition of manganese nitrate can cause more cracks and oxygen vacancies on the surface of the carrier, which is conducive to improving the dispersion of the active components on the surface of the carrier, and $\mathrm{Mn}$ can interact with $\mathrm{Ce}$ and $\mathrm{La}$ in the synthetic $(\mathrm{Ce}, \mathrm{La}) \mathrm{CO}_{3} \mathrm{~F}$ to reduce the crystallinity and increase the specific surface area. The $\mathrm{La}_{2} \mathrm{O}_{2} \mathrm{C}_{2}$ species also showed some improvement in

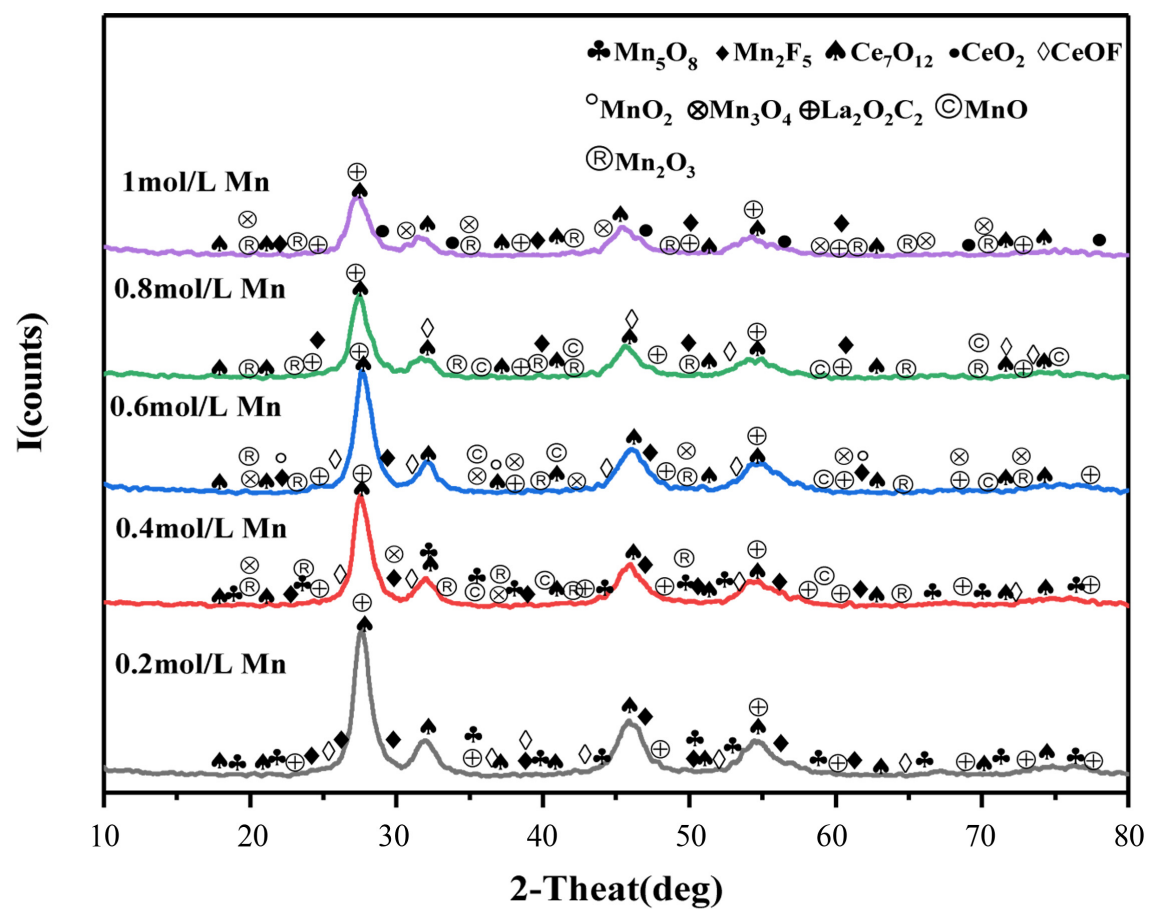

Figure 3. XRD patterns of loaded Mn. 
dispersion with increasing $\mathrm{Mn}$ loading, and from the figure, $\mathrm{MnOx}$ species such as $\mathrm{Mn}_{3} \mathrm{O}_{4}, \mathrm{Mn}_{2} \mathrm{O}_{3}, \mathrm{MnO}_{2}$ and $\mathrm{MnO}$ can also be observed. There were more $\mathrm{MnOx}$ species on the $0.8 \mathrm{~mol} / \mathrm{L}$ and $1 \mathrm{~mol} / \mathrm{L}$ catalysts compared to the less loaded catalysts. The presence of $\mathrm{MnOx}$ species is beneficial to the improvement of catalytic oxidation reduction, and the dispersion of $\mathrm{MnOx}$ species on the catalyst gradually became better, mainly in amorphous form on the catalyst surface, and the amorphous structure was favourable to the improvement of catalytic performance [5]. Due to the multiple valence states of $\mathrm{Mn}^{\mathrm{n}+}$, the interconversion of manganese ions facilitates the redox performance of the catalyst as well as the oxygen migration, both of which are beneficial for the conversion of $\mathrm{NO}$ to $\mathrm{NO}_{2}$. Generally speaking too high a loading will lead to a decrease in NO removal, this is because the dispersion of the transition metal in the catalyst starts to decrease, which leads to a conversion of the active material in the catalyst from an amorphous form to a crystalline form. It can be found that the highest catalytic activities of the catalysts with $0.8 \mathrm{~mol} / \mathrm{L}$ and $1 \mathrm{~mol} / \mathrm{L} \mathrm{Mn}$ loading amounts are similar and basically close to each other. This indicates that the dispersion of $\mathrm{Mn}$ within the catalyst has tended to decrease. However, due to the poor redox and $\mathrm{NH}_{3}$ adsorption capacity of synthetic $(\mathrm{Ce}, \mathrm{La}) \mathrm{CO}_{3} \mathrm{~F}$, the synthetic $(\mathrm{Ce}, \mathrm{La}) \mathrm{CO}_{3} \mathrm{~F}$ can be loaded with more $\mathrm{Mn}$ than other carriers and maintain a stable denitrification effect. It can also be observed from the figure that composite peaks of $\mathrm{Ce}_{7} \mathrm{O}_{12}$ species and $\mathrm{MnOx}$ species appear at $36.8^{\circ}, 38.5^{\circ}$ and $55^{\circ}$ in a companion relationship, which indicates that a $\mathrm{Mn}$-Ce solid solution may have formed on the catalyst surface. In support of this conclusion, calculations of the cell constants were carried out for the Mn-loaded catalysts and the results are shown in Table 1. Compared with the synthesis of $(\mathrm{Ce}, \mathrm{La}) \mathrm{CO}_{3} \mathrm{~F}$, the crystal plane spacing and grain size of the catalyst decreased after loading $\mathrm{Mn}$, and it was not until the crystal plane spacing increased that the surface structure of $\mathrm{Mn} /(\mathrm{Ce}, \mathrm{La}) \mathrm{CO}_{3} \mathrm{~F}$ was the most stable. The decrease in lattice parameters indicates that some of the $\mathrm{Mn}^{\mathrm{n}+}$ has entered the lattice of $(\mathrm{Ce}, \mathrm{La}) \mathrm{CO}_{3} \mathrm{~F}$ to form a $\mathrm{Mn}$-Ce-La solid solution, due to the ionic radii of $\mathrm{Mn}^{\mathrm{n}+}$ being $\mathrm{Mn}^{2+}(0.65 \AA), \mathrm{Mn}^{3+}(0.58 \AA), \mathrm{Mn}^{4+}(0.53 \AA)$, and $\mathrm{Ce}^{\mathrm{n}+}$ being $\mathrm{Ce}^{4+}(0.97 \AA), \mathrm{Ce}^{3+}(1.14 \AA)$, and $\mathrm{La}^{3+}(1.16 \AA)$ in $(\mathrm{Ce}, \mathrm{La}) \mathrm{CO}_{3} \mathrm{~F}$. Since the ionic radii of $\mathrm{Mn}^{\mathrm{n}+}$ are all smaller than Ce and La ions, the smaller ionic radii can replace the larger ones. When $\mathrm{Ce}^{4+}(0.97 \AA), \mathrm{Ce}^{3+}(1.14 \AA)$ and $\mathrm{La}^{3+}$

Table 1. Cell constants of catalysts.

\begin{tabular}{ccc}
\hline catalysts & Grain spacing $\mathrm{D}(\mathrm{nm})$ & Grain size \\
\hline$(\mathrm{Ce}, \mathrm{La}) \mathrm{CO}_{3} \mathrm{~F}$ & 5.014 & 280 \\
$\mathrm{Mn}(0.2 \mathrm{~mol} / \mathrm{L}) /(\mathrm{Ce}, \mathrm{La}) \mathrm{CO}_{3} \mathrm{~F}$ & 4.552 & 160 \\
$\mathrm{Mn}(0.4 \mathrm{~mol} / \mathrm{L}) /(\mathrm{Ce}, \mathrm{La}) \mathrm{CO}_{3} \mathrm{~F}$ & 4.486 & 168 \\
$\mathrm{Mn}(0.6 \mathrm{~mol} / \mathrm{L}) /(\mathrm{Ce}, \mathrm{La}) \mathrm{CO}_{3} \mathrm{~F}$ & 4.486 & 164 \\
$\mathrm{Mn}(0.8 \mathrm{~mol} / \mathrm{L}) /(\mathrm{Ce}, \mathrm{La}) \mathrm{CO}_{3} \mathrm{~F}$ & 4.389 & 154 \\
$\mathrm{Mn}(1.0 \mathrm{~mol} / \mathrm{L}) /(\mathrm{Ce}, \mathrm{La}) \mathrm{CO}_{3} \mathrm{~F}$ & 4.345 & 142 \\
\hline
\end{tabular}


(1.16 $\AA$ ) are replaced by $\mathrm{Mn}^{\mathrm{n}+}$ with smaller ionic radii, it will lead to changes in the lattice parameters. In addition, the grain size of $\mathrm{Mn}$-doped $(\mathrm{Ce}, \mathrm{La}) \mathrm{CO}_{3} \mathrm{~F}$ is much smaller than when undoped due to the formation of Mn-Ce-La solid solution, which inhibits grain growth and causes lattice shrinkage, making the grain size smaller. It has also been reported in the literature that the formation of the Ce-M (metal ion)-O solid solution can inhibit the growth of metal oxide crystals and promote the activation of oxygen species, thus accelerating the $\mathrm{NH}_{3}-\mathrm{SCR}$ reaction [6].

\subsection{Specific Surface Area Analysis}

Figure 4(a) and Figure 4(b) showed the isothermal curves of $\mathrm{N}_{2}$ adsorption-desorption for different catalysts respectively, and Table 2 showed the specific surface area, pore capacity and pore size of each catalyst.

From Figure 4(a) it can be seen that the synthetic (Ce, $\mathrm{La}) \mathrm{CO}_{3} \mathrm{~F}$ catalysts exhibit a type II adsorption-desorption isotherm curve, such that the curve often occurs on non-porous solid surfaces or on macroporous solids free of a single

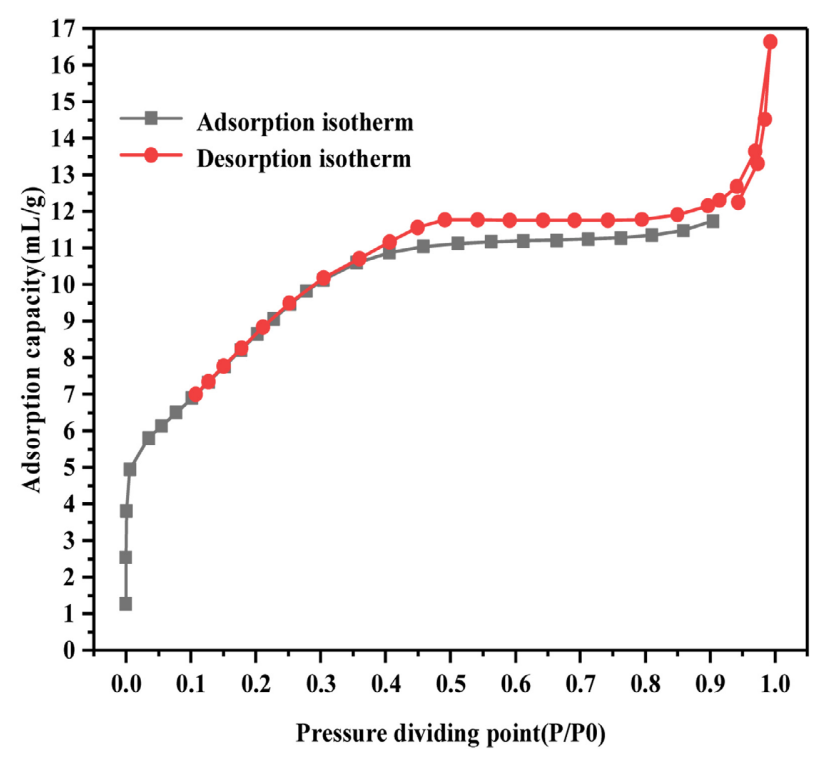

(a)

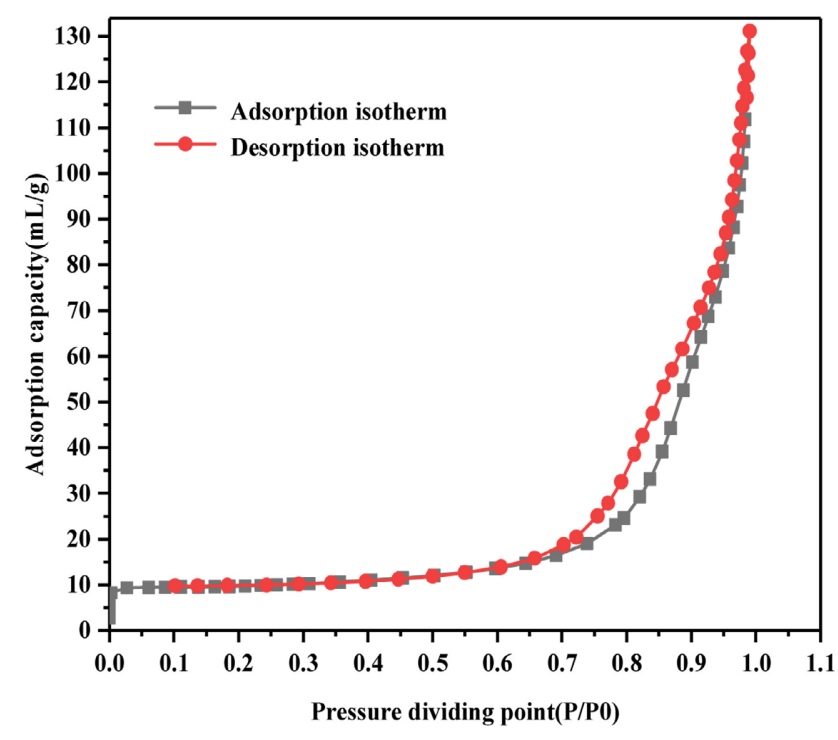

(b)

Figure 4. Adsorption-desorption isotherm profile of the catalyst. (a) (Ce,La) $\mathrm{CO}_{3} \mathrm{~F}$; (b) $\mathrm{Mn}(1.0 \mathrm{~mol} / \mathrm{L}) /(\mathrm{Ce}, \mathrm{La}) \mathrm{CO}_{3} \mathrm{~F}$.

Table 2. Catalyst specific surface area data.

\begin{tabular}{cccc}
\hline Catalysts & BET surface area $\left(\mathrm{m}^{2} / \mathrm{g}\right)$ & Pore volume $\left(\mathrm{cm}^{3} / \mathrm{g}\right)$ & Pore diameter $(\mathrm{nm})$ \\
\hline$(\mathrm{Ce}, \mathrm{La}) \mathrm{CO}_{3} \mathrm{~F}$ & 50.32 & 0.1746 & 21.7867 \\
$\mathrm{Mn}(0.2 \mathrm{~mol} / \mathrm{L})$ & 44.56 & 0.1788 & 22.3824 \\
$\mathrm{Mn}(0.4 \mathrm{~mol} / \mathrm{L})$ & 43.72 & 0.1847 & 22.4263 \\
$\mathrm{Mn}(0.6 \mathrm{~mol} / \mathrm{L})$ & 43.87 & 0.1875 & 22.7875 \\
$\mathrm{Mn}(0.8 \mathrm{~mol} / \mathrm{L})$ & 45.83 & 0.1986 & 24.4689 \\
$\mathrm{Mn}(1.0 \mathrm{~mol} / \mathrm{L})$ & 45.41 & 0.2034 & 26.4853 \\
\hline
\end{tabular}


multilayer reversible adsorption process. The curve is characterised by an inflection point at low $\mathrm{P} / \mathrm{P} 0$, the first steep part of the isotherm, which indicated the saturated adsorption capacity of the monomolecular layer, and from Figure 4(a) it can be concluded that synthetic ( $\mathrm{Ce}, \mathrm{La}) \mathrm{CO}_{3} \mathrm{~F}$ has a poor adsorption capacity at low pressures. However, as the relative pressure increases, a second layer begins to form, and at saturation vapour pressure the number of adsorption layers is infinite, which also indicated a larger increase in adsorption capacity. The type II isotherm, commonly encountered at adsorbent pore sizes greater than $20 \mathrm{~nm}$, has no upper limit to the solid pore size. In the low P/P0 region, the convex upward curve reflects a stronger interaction between the adsorbent and the adsorbate. In contrast, after doping with $\mathrm{Mn}$, as shown in Figure 4(b), the $\mathrm{Mn} /(\mathrm{Ce}, \mathrm{La}) \mathrm{CO}_{3} \mathrm{~F}$ catalyst exhibits a Type III adsorption-desorption isotherm curve, which can be found to have no inflection point in the entire pressure range, and is convex downwards, often presenting this type when the adsorption interaction between the solid and the adsorbate is smaller than the interaction between the adsorbates. The small amount of adsorption in the low pressure region, and the absence of an inflection point, indicated that the forces between the adsorbent and the adsorbate were rather weak. The higher the relative pressure, the higher the adsorption amount, which showed a pore filling, which indicated that $(\mathrm{Ce}, \mathrm{La}) \mathrm{CO}_{3} \mathrm{~F}$ has a rich pore structure when used as a carrier, which facilitates the entry and exit of the loaded metal ions and the reaction gas. As can be seen from Table 2, the physical structure of the carrier is affected by the loaded of the active component, and the specific surface area of the catalysts all decreased after loaded with the transition metal $\mathrm{Mn}$, while the pore capacity and pore size increased. It has been reported in the literature that the pore size of the catalyst is in the mesoporous range, and that an appropriate increase in the pore radius of the catalyst facilitates the adsorption and desorption of the reacting gas molecules at the active sites on the catalyst surface, thus being more conducive to the catalytic reaction [7]. The increase in pore volume pore size is also due to the interaction of $\mathrm{Mn}, \mathrm{Ce}$ and $\mathrm{La}$ to promote dispersion of each other, and facilitate the entry and exit of the reaction gases. However, it can also be found that the $\mathrm{Mn} /(\mathrm{Ce}, \mathrm{La}) \mathrm{CO}_{3} \mathrm{~F}$ catalyst made by impregnation in a $1 \mathrm{~mol} / \mathrm{L}$ manganese nitrate solution has the best denitrification effect but not the largest specific surface area, which indicated that the specific surface area is only one of the factors affecting the catalytic activity and is not the main reason [8].

\subsection{Redox and Adsorption and Desorption Performance Analysis}

Figure 5(a) showed the $\mathrm{NH}_{3}$-TPD diagram of $\mathrm{Mn} /(\mathrm{Ce}, \mathrm{La}) \mathrm{CO}_{3} \mathrm{~F}$ catalyst obtained after ultrasonic impregnation of $\mathrm{Mn}$ loaded at different concentrations. Firstly, it can be seen from Figure 5(a) that the catalysts obtained by impregnation with $0.4 \mathrm{~mol} / \mathrm{L}$ and $0.6 \mathrm{~mol} / \mathrm{L}$ manganese nitrate solutions showed a similar trend in the desorption peak of $\mathrm{NH}_{3}$, and the catalysts obtained by impregnation with $0.8 \mathrm{~mol} / \mathrm{L}$ and $1.0 \mathrm{~mol} / \mathrm{L}$ manganese nitrate solutions have similar peak positions. Usually the binding of $\mathrm{NH}_{3}$ to the Brønsted acid site and the weak Lewis 


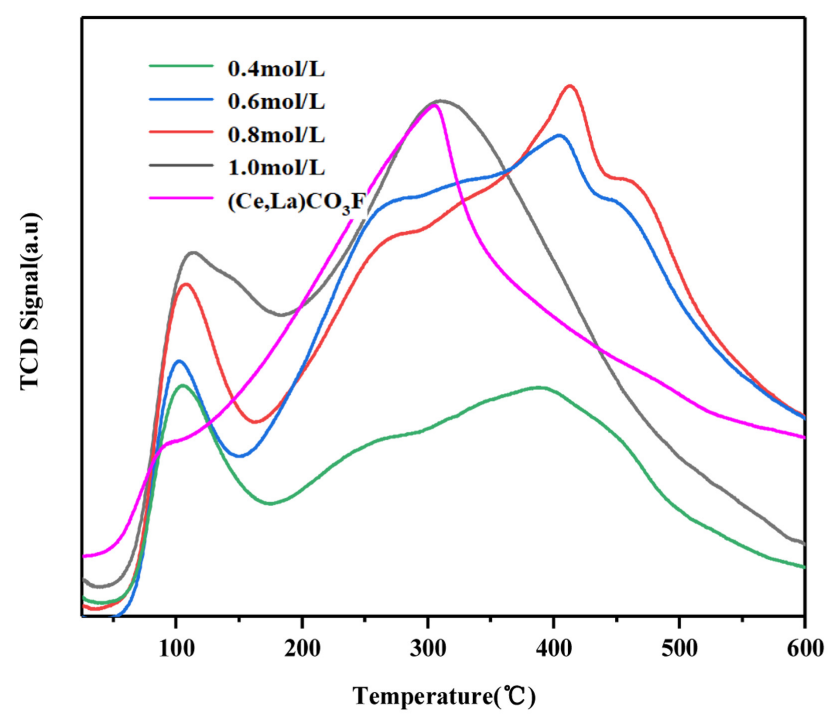

(a)

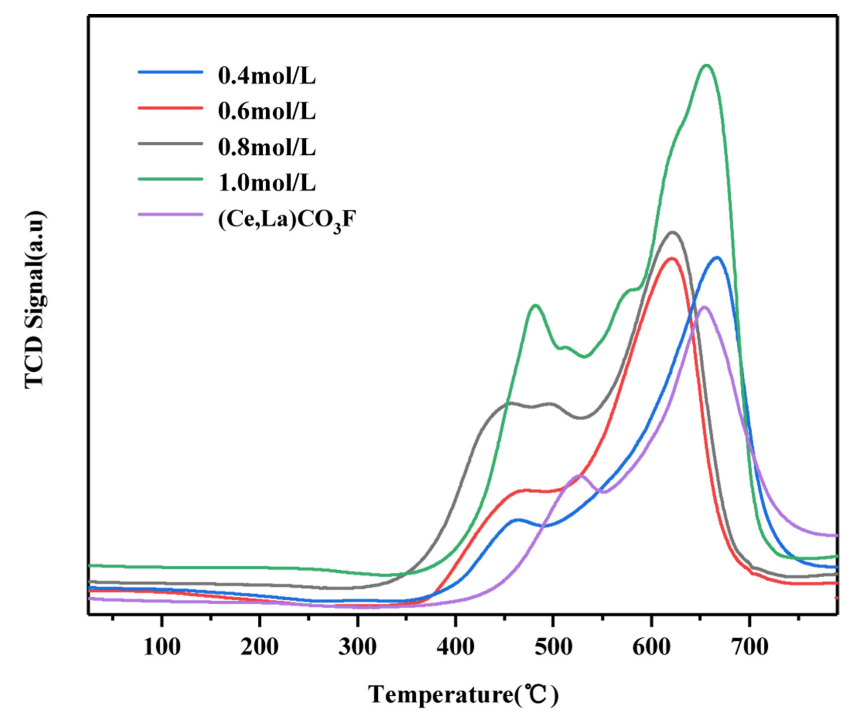

(b)

Figure 5. $\mathrm{NH}_{3}$-TPD (a) $\mathrm{H}_{2}$-TPR (b) with different ratios of loaded Mn.

acid site is around $200^{\circ} \mathrm{C}$. The desorption peaks in the $400^{\circ} \mathrm{C}$ range are caused by the desorption of ammonia at the moderately acidic site and the $500^{\circ} \mathrm{C}$ peak is caused by the binding of ammonia to the strong Lewis acid site [9] [10]. The graph showed that the $(\mathrm{Ce}, \mathrm{La}) \mathrm{CO}_{3} \mathrm{~F}$ sample showed a shoulder peak near $93^{\circ} \mathrm{C}$, where the desorption peak belonged to the binding of $\mathrm{NH}_{3}$ to the weak Brønsted acidic site, and at $312^{\circ} \mathrm{C}$, where the peak belonged to the binding of $\mathrm{NH}_{3}$ to the Brønsted acidic site and the medium Lewis acidic site. The Mn-loaded catalysts all showed a strong $\mathrm{NH}_{3}$ desorption peak at around $100^{\circ} \mathrm{C}$. The Mn-loaded catalysts all showed a strong $\mathrm{NH}_{3}$ desorption peak at around $100^{\circ} \mathrm{C}$. The desorption peak that appeared here belonged to the desorption of $\mathrm{NH}_{3}$ from the physisorbed state on the weak acidic sites and the dissociation of the Brønsted acidic sites, possibly accompanied by the binding to the weak Lewis acidic sites [11], Which indicated that the loading of the transition metal Mn increased the activity of the Brønsted acidic sites on the catalyst surface, number of acidic sites, resulting in increased activity in the low temperature section.

The $\mathrm{NH}_{3}$ desorption peak at $310^{\circ} \mathrm{C}$ for the catalyst impregnated in $0.6 \mathrm{~mol} / \mathrm{L}$ solution belonged to the strong adsorption of $\mathrm{NH}_{3}$ on the Brønsted acidic site and the moderate adsorption on the Lewis acidic site. The other three Mn-loaded catalysts all showed $\mathrm{NH}_{3}$ desorption peaks within $390^{\circ} \mathrm{C}-460^{\circ} \mathrm{C}$. Here the desorption peaks were caused by the combination of $\mathrm{NH}_{3}$ and moderate Lewis acidic sites [10], which indicated that the addition of the manganese nitrate solution resulted in a greater abundance of acidic sites on the catalyst surface. The peak area is generally considered to indicate the number of acidic sites. From Table 3, it can be obtained that the peak area gradually increased with the increase of loading, which indicated that the adsorption capacity of $\mathrm{NH}_{3}$ gradually increased, which was consistent with the activity test results. It is not difficult to find that the adsorption capacity of $\mathrm{NH}_{3}$ on the catalyst surface was 
Table 3. Peak areas of $\mathrm{NH}_{3}$-TPD adsorption and desorption curves.

\begin{tabular}{ccc}
\hline catalysts & $\begin{array}{c}\text { Peak temperature } \\
\left(\mathrm{T} /{ }^{\circ} \mathrm{C}\right)\end{array}$ & Peak area \\
\hline$(\mathrm{Ce}, \mathrm{La}) \mathrm{CO}_{3} \mathrm{~F}$ & 93,312 & 2031.3 \\
$\mathrm{Mn}(0.4 \mathrm{~mol} / \mathrm{L}) /(\mathrm{Ce}, \mathrm{La}) \mathrm{CO}_{3} \mathrm{~F}$ & 102,391 & 590.96 \\
$\mathrm{Mn}(0.6 \mathrm{~mol} / \mathrm{L}) /(\mathrm{Ce}, \mathrm{La}) \mathrm{CO}_{3} \mathrm{~F}$ & 114,310 & 1169.18 \\
$\mathrm{Mn}(0.8 \mathrm{~mol} / \mathrm{L}) /(\mathrm{Ce}, \mathrm{La}) \mathrm{CO}_{3} \mathrm{~F}$ & $100,408,458$ & 1433.14 \\
$\mathrm{Mn}(1.0 \mathrm{~mol} / \mathrm{L}) /(\mathrm{Ce}, \mathrm{La}) \mathrm{CO}_{3} \mathrm{~F}$ & $105,415,464$ & 1443.26 \\
\hline
\end{tabular}

significantly enhanced when Mn elements were introduced into the synthetic $(\mathrm{Ce}, \mathrm{La}) \mathrm{CO}_{3} \mathrm{~F}$, and the adsorption capacity also increased with increasing loading, which indicated that the enhancement of the adsorption performance originated from chemical action [12].

Figure 5 (b) showed the $\mathrm{H}_{2}$-TPR patterns of the $(\mathrm{Ce}, \mathrm{La}) \mathrm{CO}_{3} \mathrm{~F}$ and $\mathrm{Mn} /(\mathrm{Ce}, \mathrm{La}) \mathrm{CO}_{3} \mathrm{~F}$ catalysts, From Figure $5(\mathrm{~b})$, it can be seen that the $(\mathrm{Ce}, \mathrm{La}) \mathrm{CO}_{3} \mathrm{~F}$ catalyst showed a reduction peak at $521^{\circ} \mathrm{C}$, where the reduction peak is attributed to the reduction of $\mathrm{Ce}^{4+}$ to $\mathrm{Ce}^{3+}$ [13], and with the increase in temperature, the reduction peak at $651^{\circ} \mathrm{C}$ which was attributed to the reduction of the catalyst bulk phase $\mathrm{CeO}_{2}$ [14]. The oxide of $\mathrm{La}$ in $(\mathrm{Ce}, \mathrm{La}) \mathrm{CO}_{3} \mathrm{~F}$ was $\mathrm{La}_{2} \mathrm{O}_{3}$, which also has a +2 valence state based on the arrangement of its outer electrons, and since $\mathrm{La}, \mathrm{Ce}$ are neighbouring rare earth elements with relatively similar chemical properties, La may also have some redox ability. The catalysts loaded with $\mathrm{Mn}$ all showed reduction peaks at $450^{\circ} \mathrm{C}-490^{\circ} \mathrm{C}$. The reduction peaks here can be attributed to the process of $\mathrm{MnO}_{2} / \mathrm{Mn}_{2} \mathrm{O}_{3} \rightarrow \mathrm{Mn}_{3} \mathrm{O}_{4} \rightarrow \mathrm{MnO}$ conversion [15] [16], and due to the large number of $\mathrm{MnOx}$ species, the reaction process can be interconverted, which facilitates the redox reaction. The catalyst obtained by impregnation in a $0.4 \mathrm{~mol} / \mathrm{L}$ solution, apart from the reduction of $\mathrm{Mn}^{\mathrm{n}+}$ at $452^{\circ} \mathrm{C}$, the obvious change was the enhanced reduction of the bulk phase $\mathrm{CeO}_{2}$ at $661^{\circ} \mathrm{C}$ and promoted the reaction. With increased loading, the position of the reduction peak of the bulk phase $\mathrm{CeO}_{2}$ shifted towards the low temperature section, and the $\mathrm{H}_{2}$ adsorption also increased significantly, Which indicated that strong electronic interactions between the $\mathrm{MnOx}$ species on the catalyst surface and $\mathrm{CeO}_{2}$ occurred, and the interactions promoted the reduction of $\mathrm{Ce}^{4+}$ on the surface. From Table 4, it can be seen the catalyst obtained by impregnation in $1.0 \mathrm{~mol} / \mathrm{L}$ solution had the largest peak area compared to the other Mn-loaded catalysts, which indicated a higher redox capacity, the most active reduction of $\mathrm{Ce}^{4+}$ to $\mathrm{Ce}^{3+}$ under these conditions, the increase in the reduction potential of the active component, the formation of oxygen vacancies and more oxygen species, which facilitated the migration of oxygen and enhanced the activation reaction of the catalyst, and the catalyst has excellent redox ability.

\subsection{Surface Element Valence Analysis}

Figure 6(a) showed the Ce 3d spectrum. From Figure 6(a) it can be seen that 
Table 4. Peak areas of $\mathrm{H}_{2}$-TPR adsorption and desorption curves.

\begin{tabular}{ccc}
\hline catalysts & Peak temperature $\left(\mathrm{T} /{ }^{\circ} \mathrm{C}\right)$ & Peak area \\
\hline$(\mathrm{Ce}, \mathrm{La}) \mathrm{CO}_{3} \mathrm{~F}$ & 521,651 & 7320.32 \\
$\mathrm{Mn}(0.4 \mathrm{~mol} / \mathrm{L}) /(\mathrm{Ce}, \mathrm{La}) \mathrm{CO}_{3} \mathrm{~F}$ & 452,661 & 7173.75 \\
$\mathrm{Mn}(0.6 \mathrm{~mol} / \mathrm{L}) /(\mathrm{Ce}, \mathrm{La}) \mathrm{CO}_{3} \mathrm{~F}$ & 456,613 & 6978.59 \\
$\mathrm{Mn}(0.8 \mathrm{~mol} / \mathrm{L}) /(\mathrm{Ce}, \mathrm{La}) \mathrm{CO}_{3} \mathrm{~F}$ & $442,489,613$ & 9725.08 \\
$\mathrm{Mn}(1.0 \mathrm{~mol} / \mathrm{L}) /(\mathrm{Ce}, \mathrm{La}) \mathrm{CO}_{3} \mathrm{~F}$ & $468,571,648$ & $13,107.51$ \\
\hline
\end{tabular}

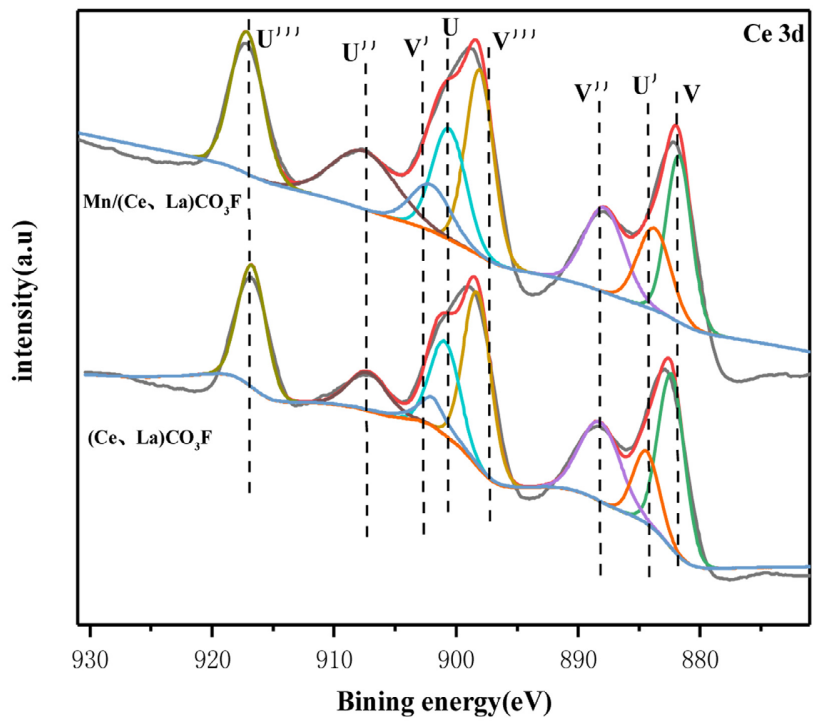

(a)

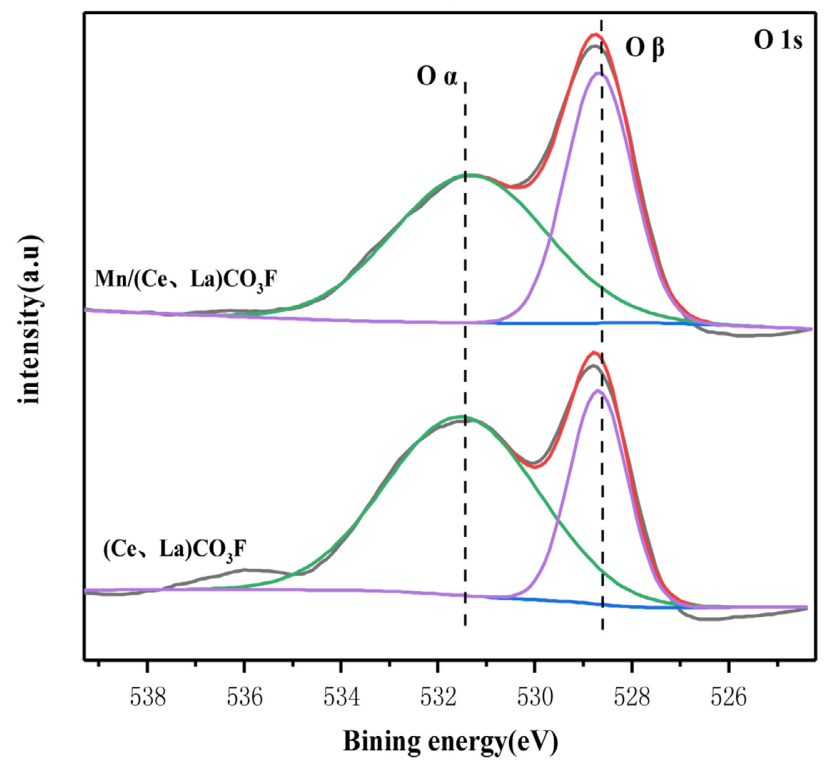

(c)

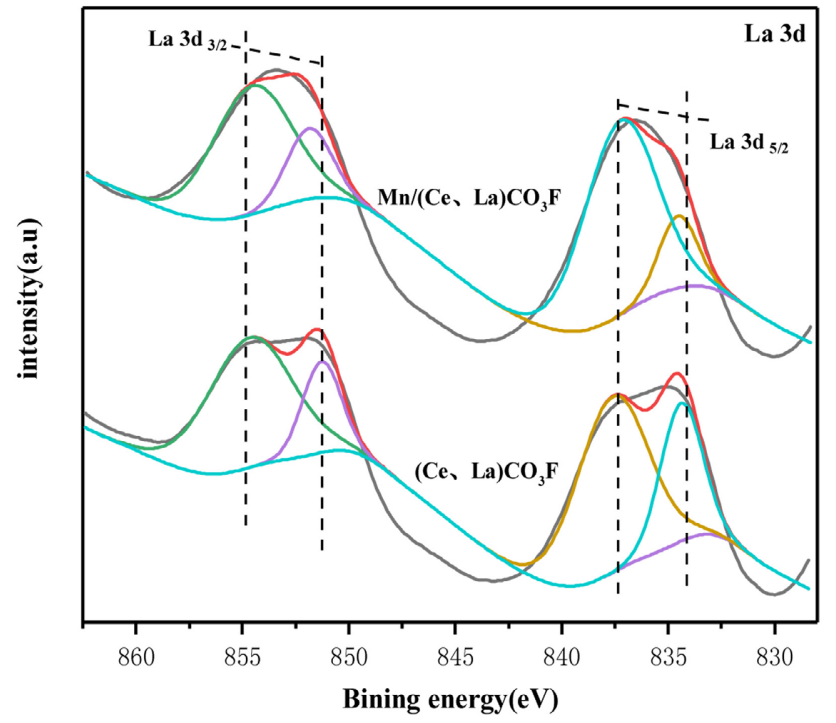

(b)

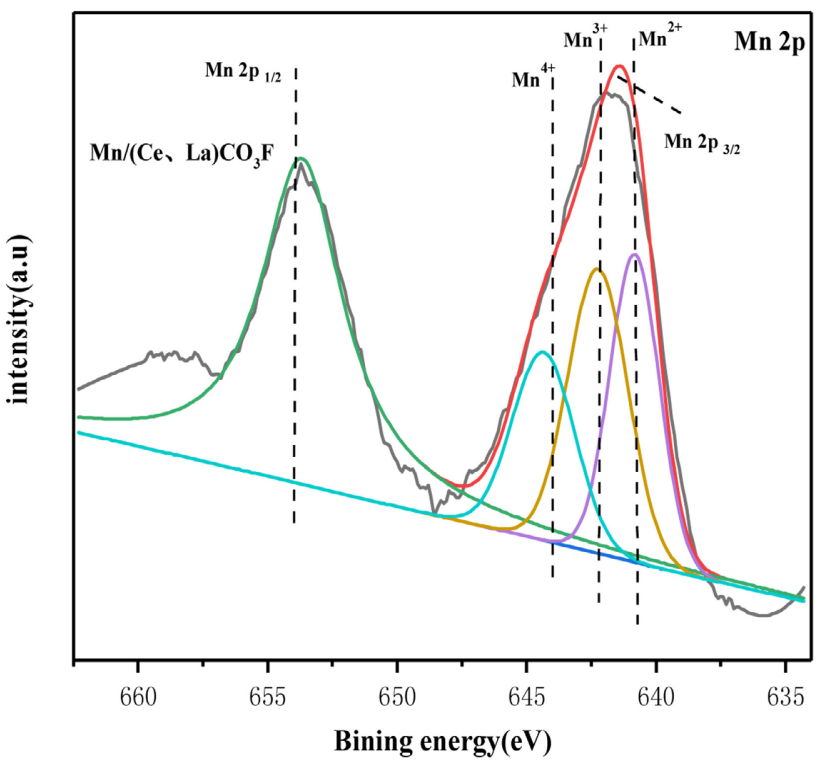

(d)

Figure 6. XPS with different catalysts.

the Ce $3 \mathrm{~d}$ spectrum contains eight characteristic peaks. Of these, $\mathrm{u}(900.8 \mathrm{ev}), \mathrm{u}$ (907.5 ev), u"' (916.5 ev), v (882.3 ev), v" (888.9 ev), v"' (898.4 ev) were attributed 
to $\mathrm{Ce}^{4+} . \mathrm{u}^{\prime}(903.8 \mathrm{ev}), \mathrm{v}^{\prime}(884.7 \mathrm{ev})$ had characteristic peaks that belonged to $\mathrm{Ce}^{3+}$ [17] [18]. It is obviously evident from Figure 6(a) that the $\mathrm{Mn} /(\mathrm{Ce}, \mathrm{La}) \mathrm{CO}_{3} \mathrm{~F}$ catalyst has a stronger peak at $\mathrm{u}^{\prime}, \mathrm{v}^{\prime}$ compared to the $(\mathrm{Ce}, \mathrm{La}) \mathrm{CO}_{3} \mathrm{~F}$ catalyst, which implies an increased $\mathrm{Ce}^{3+}$ content on the catalyst surface. The higher $\mathrm{Ce}^{3+} /\left(\mathrm{Ce}^{4+}+\mathrm{Ce}^{3+}\right)$ ratio indicated that this catalyst exhibited an unsaturated chemical energy band and more oxygen vacancies, which would promote the adsorption of $\mathrm{NH}_{3}$ from the reactant [19] [20] [21], which is consistent with the results of $\mathrm{NH}_{3}$-TPD. The proportion of each type of element is calculated in Table 5, from which it can be obtained that by loading the transition metal $\mathrm{Mn}$, the content of $\mathrm{Ce}^{3+}$ does increase compared to the original carrier, which indicated that the introduction of $\mathrm{Mn}^{\mathrm{n}+}$ can cause $\mathrm{Mn}$, Ce interaction, which makes part of $\mathrm{Ce}^{4+}$ to convert into $\mathrm{Ce}^{3+}$, promoting the redox ability of each other, which is beneficial to the SCR reaction. The elevated content of $\mathrm{Ce}^{3+}$ is beneficial to promote the transfer of oxygen on the catalyst surface and the regeneration of the active site in the redox cycle reaction.

Figure 6(b) showed the La 3d spectrum with electron binding energies of magnitude 854 - $855 \mathrm{ev}, 850$ - $851 \mathrm{ev}, 837$ - $838 \mathrm{ev}$ and 833 - $834 \mathrm{ev}$ [22]. The characteristic peaks of lanthanum metal are double peaks. When lanthanum metal forms a composite oxide $\mathrm{La}_{3} \mathrm{~d}_{3 / 2}$ and $\mathrm{La}_{3} \mathrm{~d}_{5 / 2}$ appear as companion peaks. The reason for the appearance of the companion peaks was the ionisation of electrons in the inner shell layers of $\mathrm{La}_{3 / 2}$ and $\mathrm{La}_{3} \mathrm{~d}_{5 / 2}$, and the transfer of $2 \mathrm{p}$ valence electrons from the ligand oxygen with La to the $4 \mathrm{f}$ vacant orbital of La, causing the splitting of the La3d characteristic peak, which leads to the result of the vibronic companion peaks of $\mathrm{La}_{3} \mathrm{~d}_{3 / 2}$ and $\mathrm{La}_{3 / 2}$ [23] [24], where the binding energy in the $\mathrm{La} 3 \mathrm{~d}$ pattern of the synthetic $(\mathrm{Ce}, \mathrm{La}) \mathrm{CO}_{3} \mathrm{~F}$ catalyst is lower than that of the standard characteristic peak and accompanying peaks. This indicated that there is no transfer of electrons between the metals $\mathrm{La}$ [25] and that a Ce-La-O solid solution may be formed here [26]. When loaded with the transition metal $\mathrm{Mn}$, the electron binding energy of $\mathrm{La} \mathrm{d}_{5 / 2}$ was shifted more towards the lower end, probably due to the introduction of a third metal, which enhanced the inter-elemental interactions forming a new solid solution (Mn-Ce-La), which is consistent with the $\mathrm{XRD}$ results.

Figure 6(c) showed the $O 1$ s spectrum of catalyst. The peak at $531.3 \mathrm{ev}$ belonged to the surface adsorbed oxygen species, denoted as $\mathrm{Oa}$, and the peak at $529.5 \mathrm{ev}$ belonged to the lattice oxygen species, denoted as $O \beta$ [27]. As can be seen from Figure $6(\mathrm{c})$, after loading with $\mathrm{Mn}$, the lattice oxygen peak is slightly enhanced, but the adsorbed oxygen peak is weakened, but is similar to $(\mathrm{Ce}, \mathrm{La}) \mathrm{CO}_{3} \mathrm{~F}$. The chemisorbed oxygen $(\mathrm{O \alpha})$ is the most active oxygen species

Table 5. Fitted data of XPS on the catalyst.

\begin{tabular}{cccc}
\hline samples & $\mathrm{Ce}^{3+} /\left(\mathrm{Ce}^{3+}+\mathrm{Ce}^{4+}\right)(\%)$ & $\mathrm{O}_{\alpha} /\left(\mathrm{O}_{\alpha}+\mathrm{O}_{\beta}\right)(\%)$ & $\mathrm{Mn}^{4+} /\left(\mathrm{Mn}^{4+}+\mathrm{Mn}^{3+}+\mathrm{Mn}^{2+}\right)(\%)$ \\
\hline$(\mathrm{Ce}, \mathrm{La}) \mathrm{CO}_{3} \mathrm{~F}$ & 10.7 & 71.12 & - \\
$\mathrm{Mn}(1 \mathrm{~mol} / \mathrm{L}) /(\mathrm{Ce}, \mathrm{La}) \mathrm{CO}_{3} \mathrm{~F}$ & 13.16 & 63.3 & 14.54 \\
\hline
\end{tabular}


and plays a key role in the redox reaction [28]. From the calculations in Table 5, it can be seen that the $(\mathrm{Ce}, \mathrm{La}) \mathrm{CO}_{3} \mathrm{~F}$ catalyst itself contains more surface adsorbed oxygen, and after loading with transition metals, the proportion of adsorbed oxygen decreases, which is probably because the addition of $\mathrm{Mn}$ does not contribute to the increase of chemisorbed oxygen $(\mathrm{Oa}) .(\mathrm{Ce}, \mathrm{La}) \mathrm{CO}_{3} \mathrm{~F}$ and the catalyst after loading with the transition metal $\mathrm{Mn}$, the binding energy of $\mathrm{O} 1 \mathrm{~s}$ shifted slightly towards the lower compared to the standard binding energy. This suggested that $\mathrm{O}$ and the metal element interacted to form the Mn-O-Ce(La) species, which shifted to a lower binding energy due to its shorter bond length [29] [30].

Figure 6(d) showed the $\mathrm{Mn} 2 \mathrm{p}$ spectrum for the $\mathrm{Mn} /(\mathrm{Ce}, \mathrm{La}) \mathrm{CO}_{3} \mathrm{~F}$ catalyst. From Figure 6(d), the Mn $2 \mathrm{p}$ band can be obtained as two main peaks, Mn 2 $\mathrm{p}_{1 / 2}$ $(654.2 \mathrm{ev})$ and $\mathrm{Mn} 2 \mathrm{p}_{3 / 2}(641.1 \mathrm{ev})$. The Mn $2 \mathrm{p}$ of all catalysts can be further decomposed into three peaks, where the binding energy in the range of 641.0 $641.3 \mathrm{ev}$ belonged to $\mathrm{Mn}^{2+}, 642.0-642.6 \mathrm{ev}$ to $\mathrm{Mn}^{3+}$ and $644.0-644.7 \mathrm{ev}$ to $\mathrm{Mn}^{4+}$ [31]. It is generally accepted that the catalytic capacity of $\mathrm{MnOx}$ is $\mathrm{MnO}_{2}>$ $\mathrm{Mn}_{3} \mathrm{O}_{4}>\mathrm{Mn}_{3} \mathrm{O}_{4}$ [32] [33] [34] and that the catalyst surface produces a large amount of $\mathrm{MnO}_{2}$ to facilitate the SCR reaction [35]. The reason why $\mathrm{Mn}^{4+}$ plays more of a role in the $\mathrm{NH}_{3}-\mathrm{SCR}$ reaction than $\mathrm{Mn}^{3+}$ and $\mathrm{Mn}^{2+}$ is because its high redox ability can facilitate the conversion of $\mathrm{NO}$ to $\mathrm{NO}_{2}$ and enhance the catalytic activity of the low temperature section through the fast SCR reaction: $\mathrm{NO}+$ $\mathrm{NO}_{2}+2 \mathrm{NH}_{3}=3 \mathrm{~N}_{2}+2 \mathrm{H}_{2} \mathrm{O}$, and therefore this reaction is also the main pathway for the low temperature reaction [36] [37].

\section{In-Situ Infrared Analysis and Reaction Mechanism Study \\ In-Situ Infrared Spectroscopy of $\mathrm{NH}_{3}$ and $\mathrm{NO}+\mathrm{O}_{2}$ Adsorption Stability on Catalyst Surfaces}

In order to investigate the effect of catalyst activation by $\mathrm{NH}_{3}$ adsorption at optimum temperature conditions, in-situ IR spectroscopy was carried out on (Ce,La) $\mathrm{CO}_{3} \mathrm{~F}$ and the catalysts produced after loading with $\mathrm{Mn}$. From the activity test results, it was found that $(\mathrm{Ce}, \mathrm{La}) \mathrm{CO}_{3} \mathrm{~F}$ reached the optimum activity at $200^{\circ} \mathrm{C}$, and $\mathrm{Mn}(1 \mathrm{~mol} / \mathrm{L}) /(\mathrm{Ce}, \mathrm{La}) \mathrm{CO}_{3} \mathrm{~F}$ reached the optimum denitrification efficiency at $250^{\circ} \mathrm{C}$. This experiment investigated the variation of $\mathrm{NH}_{3}$ adsorption over time for both catalysts at the optimum denitrification temperature. Figure 7 (a) showed the infrared spectra of $\mathrm{NH}_{3}$ with time for the synthetic $(\mathrm{Ce}, \mathrm{La}) \mathrm{CO}_{3} \mathrm{~F}$. From the figure, it can be seen that two distinct infrared absorption peaks appeared at $1590 \mathrm{~cm}^{-1}$ and $1301 \mathrm{~cm}^{-1}$ after $5 \mathrm{~min}$ of $\mathrm{NH}_{3}$ passage, the absorption peak at $1590 \mathrm{~cm}^{-1}$ was attributed to the $\mathrm{NH}_{3}$ species in the ligand state on the Lewis acidic site [38], and the absorption peak at $1301 \mathrm{~cm}^{-1}$ is attributed to the dehydrogenation product $\mathrm{eNH}_{2}$ produced by the dehydrogenation reaction of the activated $\mathrm{NH}_{3}$ species [39]. With increased passage time of $\mathrm{NH}_{3}$, the $\mathrm{NH}_{3}$ species adsorbed at the Lewis acidic site at $1590 \mathrm{~cm}^{-1}$ disappeared at 10 min, which indicated that it was very unstable with time. At 20 - 30 min pass, 


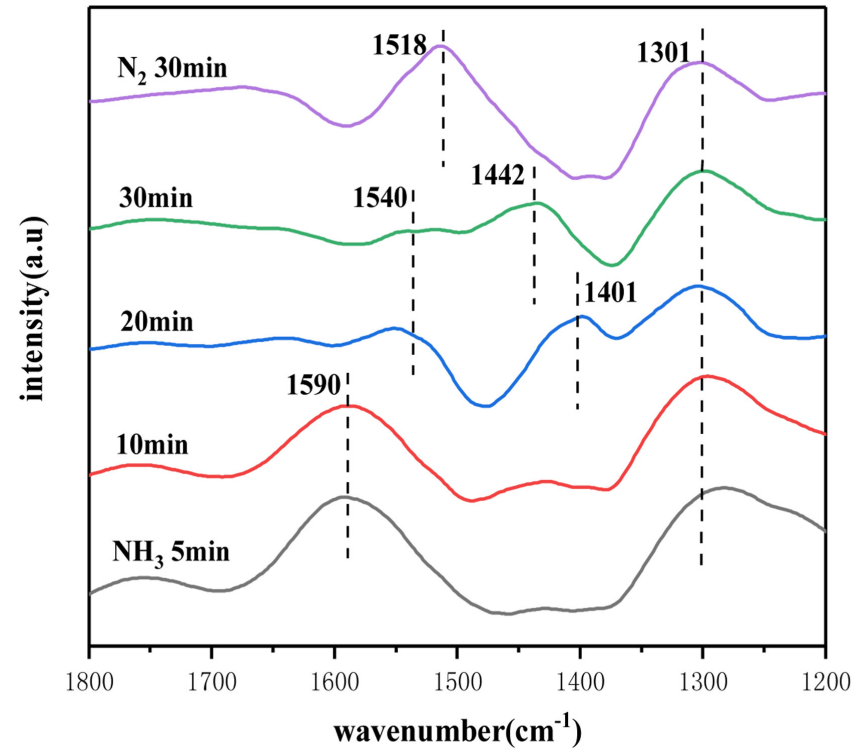

(a)

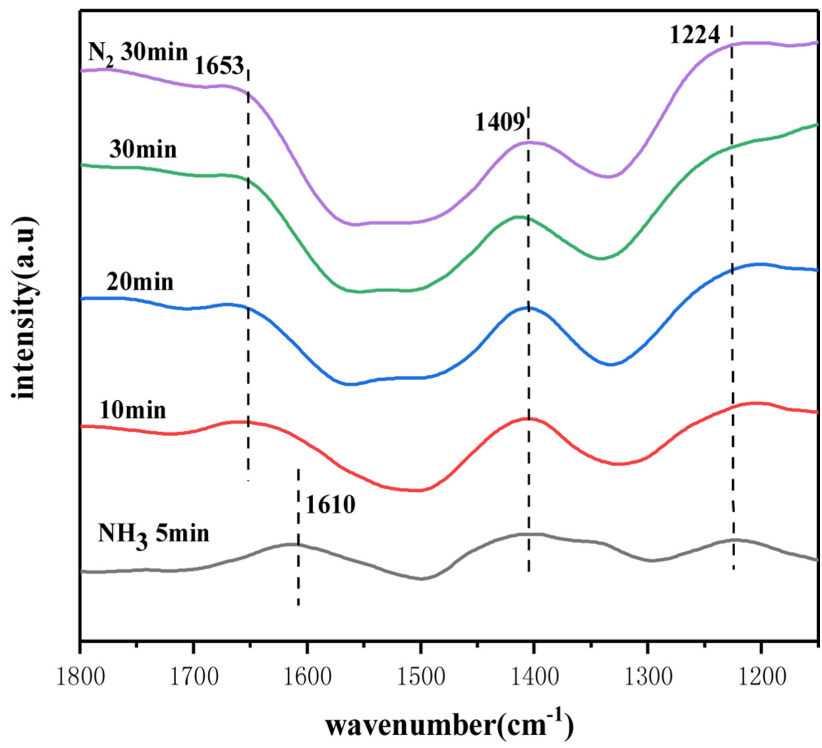

(b)

Figure 7. In-situ infrared spectra of $\mathrm{NH}_{3}$ adsorption of the catalyst at the optimal denitration temperature over time. (a) $(\mathrm{Ce}, \mathrm{La}) \mathrm{CO}_{3} \mathrm{~F}$. (b) $\mathrm{Mn}(1 \mathrm{~mol} / \mathrm{L}) /(\mathrm{Ce}, \mathrm{La}) \mathrm{CO}_{3} \mathrm{~F}$.

three IR absorption peaks appeared on the catalyst surface at $1540 \mathrm{~cm}^{-1}, 1442$ $\mathrm{cm}^{-1}$ and $1401 \mathrm{~cm}^{-1}$. The absorption peak at $1540 \mathrm{~cm}^{-1}$ was attributed to the $\mathrm{V}_{3}$ splitting pattern of bidentate nitrate, and the appearance of this peak was attributed to the oxidative adsorption of $\mathrm{NH}_{3}$ by the oxygen species on the catalyst surface [40]. The absorption peaks at $1442 \mathrm{~cm}^{-1}$ and $1401 \mathrm{~cm}^{-1}$ belonged to $\mathrm{NH}_{4}^{+}$species on the Brønsted acidic sites [41] [42], which indicated that the synthetic $(\mathrm{Ce}, \mathrm{La}) \mathrm{CO}_{3} \mathrm{~F}$ catalyst was relatively rich in acidic sites on the surface, but that these species were extremely unstable and decomposed and disappeared as the $\mathrm{NH}_{3}$ influx time changed. Finally, the stability of the $\mathrm{NH}_{3} / \mathrm{NH}_{4}^{+}$species formed was observed by purging with $\mathrm{N}_{2}$ for $30 \mathrm{~min}$. It was found that after the $\mathrm{N}_{2}$ purge, most of the $\mathrm{NH}_{3} / \mathrm{NH}_{4}^{+}$species formed on the catalyst surface disappeared, with only the dehydrogenation product $\mathrm{eNH}_{2}$ produced by the $\mathrm{NH}_{3}$ species at $1301 \mathrm{~cm}^{-1}$ remaining stable, and thus participated in the $\mathrm{NH}_{3}$-SCR reaction. Notably, after $\mathrm{N}_{2}$ purging, the catalyst showed a new IR absorption peak at $1518 \mathrm{~cm}^{-1}$, where the peak was due to the dehydrogenation of $-\mathrm{NH}_{2}$ species from $\mathrm{NH}_{3}$ species adsorbed on the Brønsted acidic site [40].

Figure 7 (b) showed the infrared spectrum of $\mathrm{NH}_{3}$ adsorption with time for the $\mathrm{Mn} /(\mathrm{Ce}, \mathrm{La}) \mathrm{CO}_{3} \mathrm{~F}$ catalyst at $250^{\circ} \mathrm{C}$. From Figure $7(\mathrm{~b})$, it can be seen that when $\mathrm{NH}_{3}$ was introduced for $5 \mathrm{~min}$, infrared absorption peaks appeared on the catalyst surface at $1610 \mathrm{~cm}^{-1}, 1409 \mathrm{~cm}^{-1}$ and $1224 \mathrm{~cm}^{-1}$, with the absorption peak at $1610 \mathrm{~cm}^{-1}$ attributed to the $\mathrm{NH}_{3}$ species in the Lewis acidic site [41], and this species disappeared quickly with increasing time, which indicated its unstable adsorption. The absorption peaks at $1409 \mathrm{~cm}^{-1}$ and $1224 \mathrm{~cm}^{-1}$ are attributed to asymmetric bending vibrations occurring in the $\mathrm{NH}_{4}^{+}$species at the Brønsted acidic site [43] [44] and the $\mathrm{NH}_{3}$ species at the Lewis acidic site, respectively. The 
infrared absorption peak at $1653 \mathrm{~cm}^{-1}$ on the catalyst surface after $10 \mathrm{~min}$ of passage belongs to the $\mathrm{NH}_{4}^{+}$species at the Brønsted acidic site [45] [46]. This indicated that $\mathrm{Mn} /(\mathrm{Ce}, \mathrm{La}) \mathrm{CO}_{3} \mathrm{~F}$ was dominated by Brønsted acidic sites on the catalyst surface at $250^{\circ} \mathrm{C}$, accompanied by a small amount of Lewis acidic sites to promote the reaction. This suggested that the use of manganese nitrate solution as a precursor could provide more Brønsted acidic sites for the catalyst. It has been reported in the literature that Brønsted acidic sites have a facilitative effect on the $\mathrm{NH}_{3}$-SCR reaction [47], and after loading, the $\mathrm{NH}_{3} / \mathrm{NH}_{4}^{+}$species produced by $\mathrm{NH}_{3}$ adsorption were more stable compared to $(\mathrm{Ce}, \mathrm{La}) \mathrm{CO}_{3} \mathrm{~F}$. The species were present in a very stable state on the catalyst surface, both with increasing $\mathrm{NH}_{3}$ influx time and $\mathrm{N}_{2}$ purging, thus facilitating the $\mathrm{NH}_{3}-\mathrm{SCR}$ reaction. In addition, the intensity of the absorption peaks of the species adsorbed on the Lewis and Brønsted acidic sites increased slightly, probably because the nitric acid caused some cracks on the catalyst surface, resulting in more oxygen vacancies on the catalyst surface, which facilitated the adsorption of $\mathrm{Ce}^{4+}$ on the acidic sites.

Compared to both catalysts, the $\mathrm{NH}_{3} / \mathrm{NH}_{4}^{+}$species formed on the surface of the $\mathrm{Mn} /(\mathrm{Ce}, \mathrm{La}) \mathrm{CO}_{3} \mathrm{~F}$ catalyst are more stable and have more Brønsted acidic sites as well as oxygen vacancies, allowing more $\mathrm{Ce}^{4+}$ in the carrier to participate in the reaction in combination with the $\mathrm{NH}_{3} / \mathrm{NH}_{4}^{+}$species.

To further investigate the effect of catalysts on $\mathrm{NO}$ adsorption and activation performance, the in-situ infrared spectra of $\mathrm{NO}+\mathrm{O}_{2}$ adsorption with time for two different catalysts at the optimum denitrification temperature conditions were also investigated, as shown in Figure 8. Figure 8(a) showed the infrared spectrum of $\mathrm{NO}+\mathrm{O}_{2}$ adsorption with time for the synthetic $(\mathrm{Ce}, \mathrm{La}) \mathrm{CO}_{3} \mathrm{~F}$ catalyst at $200^{\circ} \mathrm{C}$. It can be found that $(\mathrm{Ce}, \mathrm{La}) \mathrm{CO}_{3} \mathrm{~F}$ showed two IR absorption peaks on

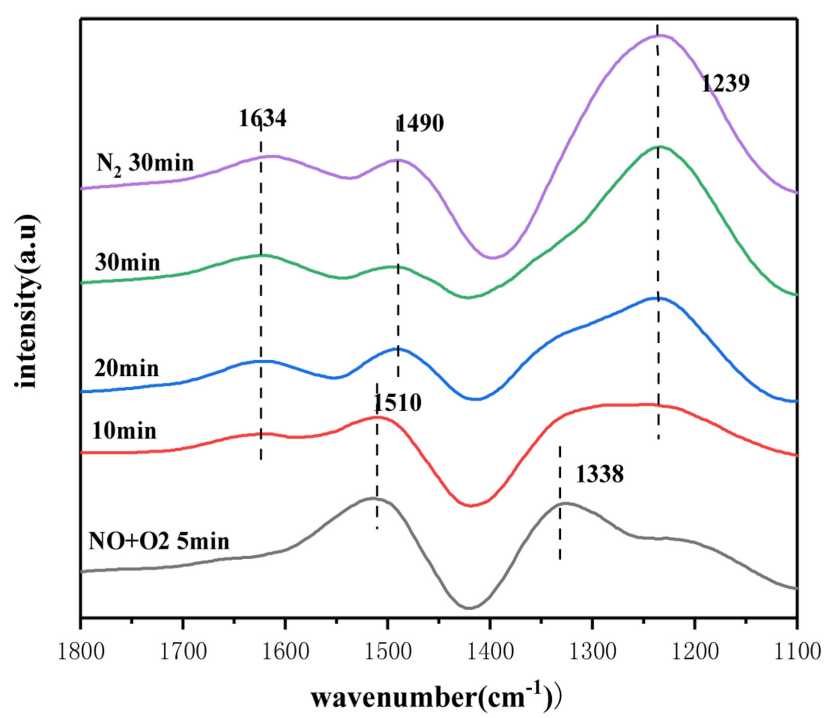

(a)

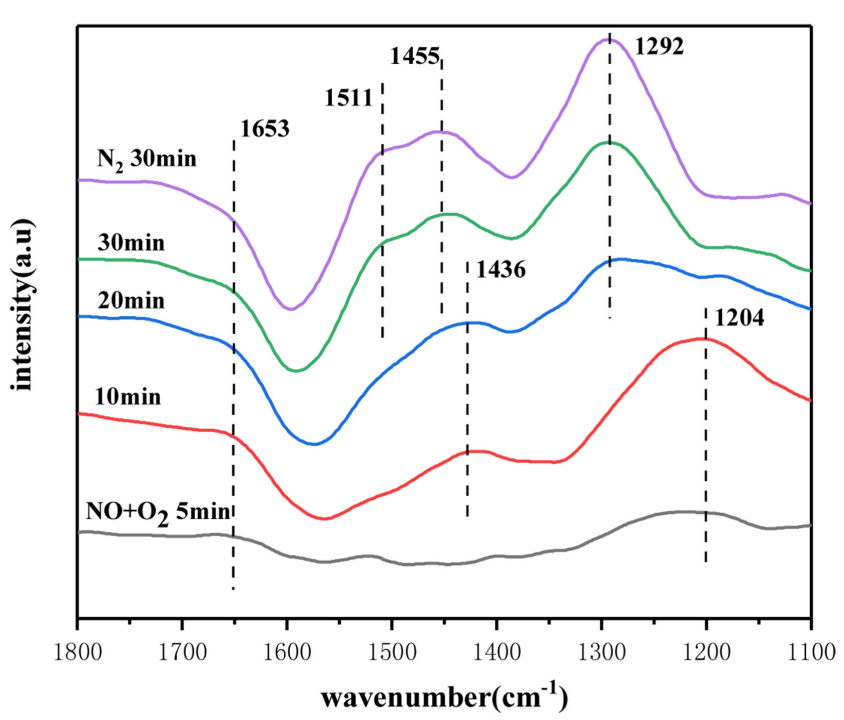

(b)

Figure 8. In-situ infrared spectra of $\mathrm{NO}+\mathrm{O}_{2}$ adsorption of the catalyst at the optimal denitration temperature over time. (a) $(\mathrm{Ce}, \mathrm{La}) \mathrm{CO}_{3} \mathrm{~F}$. (b) $\mathrm{Mn}(1 \mathrm{~mol} / \mathrm{L}) /(\mathrm{Ce}, \mathrm{La}) \mathrm{CO}_{3} \mathrm{~F}$. 
the catalyst surface at $1510 \mathrm{~cm}^{-1}$ and $1338 \mathrm{~cm}^{-1}$ at $5 \mathrm{~min}$ of $\mathrm{NO}+\mathrm{O}_{2}$ pass, the absorption peak at $1510 \mathrm{~cm}^{-1}$ belonged to a monodentate nitrate species [48], and the absorption peak at $1338 \mathrm{~cm}^{-1}$ is attributed to a bidentate nitrate species [49], with the $\mathrm{NO}+\mathrm{O}_{2}$ passage time increased, the absorption peak of the bidentate nitrate species was found to disappear gradually, which indicated that its adsorption on the catalyst surface was less stable and prone to decomposition. The absorption peak of the monodentate nitrate species at $1510 \mathrm{~cm}^{-1}$ was shifted to $1490 \mathrm{~cm}^{-1}$ at $10 \mathrm{~min}$ of $\mathrm{NO}+\mathrm{O}_{2}$, where the nitrate species was still monodentate, probably due to the large amount of monodentate nitrate species produced during the reaction. At $10 \mathrm{~min}$ IR absorption peaks appeared at $1634 \mathrm{~cm}^{-1}$ and 1239 $\mathrm{cm}^{-1}$ on the catalyst surface, the absorption peak at $1634 \mathrm{~cm}^{-1}$ belonged to the bidentate nitrate species and weak adsorption could be found. The peak at 1239 $\mathrm{cm}^{-1}$ belonged to the bridging nitrate species [49] [50]. With increasing $\mathrm{NO}+\mathrm{O}_{2}$ influx time and final purging with $\mathrm{N}_{2}$, the monodentate nitrate, bidentate nitrate and bridging nitrate species were all present on the catalyst surface in a very stable state.

Figure 8(b) showed the in situ IR spectra of $\mathrm{NO}+\mathrm{O}_{2}$ adsorption over time for the $\mathrm{Mn} /(\mathrm{Ce}, \mathrm{La}) \mathrm{CO}_{3} \mathrm{~F}$ catalyst at $250^{\circ} \mathrm{C}$. From Figure $8(\mathrm{~b})$, it can be seen that there is no obvious large trend of IR absorption peaks on the catalyst surface when $\mathrm{NO}+\mathrm{O}_{2}$ is introduced for $5 \mathrm{~min}$. With increasing $\mathrm{NO}+\mathrm{O}_{2}$ pass time, strong IR absorption peaks appeared on the catalyst surface at $1436 \mathrm{~cm}^{-1}$ and $1204 \mathrm{~cm}^{-1}$ at $10 \mathrm{~min}$. The absorption peaks at $1436 \mathrm{~cm}^{-1}$ belonged to monodentate nitrate species, and the absorption peaks at $1204 \mathrm{~cm}^{-1}$ were attributed to nitrate species bound at the $\mathrm{Mn}-\mathrm{O}-\mathrm{Ce}$ site [51] [52], and similarly at $10 \mathrm{~min}$, the absorption peak at $1653 \mathrm{~cm}^{-1}$ belonged to the bidentate nitrate species and the bidentate nitrate species was present in a very stable state as the $\mathrm{NO}+\mathrm{O}_{2}$ pass time increased. At $20 \mathrm{~min}$, the IR absorption peaks at $1511 \mathrm{~cm}^{-1}, 1455 \mathrm{~cm}^{-1}$ and $1292 \mathrm{~cm}^{-1}$ on the catalyst surface were all attributed to the monodentate species [49] [53], and the monodentate species was very stable after $\mathrm{N}_{2}$ purging. It is noteworthy that the number of monodentate nitrate species on the catalyst surface increased with $\mathrm{Mn}$ loading compared to the (Ce, $\mathrm{La}) \mathrm{CO}_{3} \mathrm{~F}$ catalyst, with a new nitrate species (bridged nitrate) appearing at $1204 \mathrm{~cm}^{-1}$ at $10 \mathrm{~min}$, so it can be judged that these nitrate species bonded to the $\mathrm{Mn}^{3+}$ provided by the loaded Mn to form intermediate products that participated in the SCR reaction. In addition, the absorption peak intensities of the monodentate nitrate species were also greatly increased by the loading of Mn.

In this experiment, the process of $\mathrm{NH}_{3}$ adsorption and activation on the catalyst surface under different temperature conditions was investigated by in situ infrared spectroscopy for both catalysts, and the forms of $\mathrm{NH}_{3}$ species present on the catalyst surface under different temperature conditions were studied. Figure 9(a) showed the spectrum of the change in thermal stability of the $\mathrm{NH}_{3}$ adsorbed species of $(\mathrm{Ce}, \mathrm{La}) \mathrm{CO}_{3} \mathrm{~F}$ in the interval of $50^{\circ} \mathrm{C}-400^{\circ} \mathrm{C}$. Firstly, it can be observed that throughout the temperature interval, two distinct infrared absorption peaks appear on the catalyst surface at $1624 \mathrm{~cm}^{-1}$ and $1317 \mathrm{~cm}^{-1}$. The absorption peak 


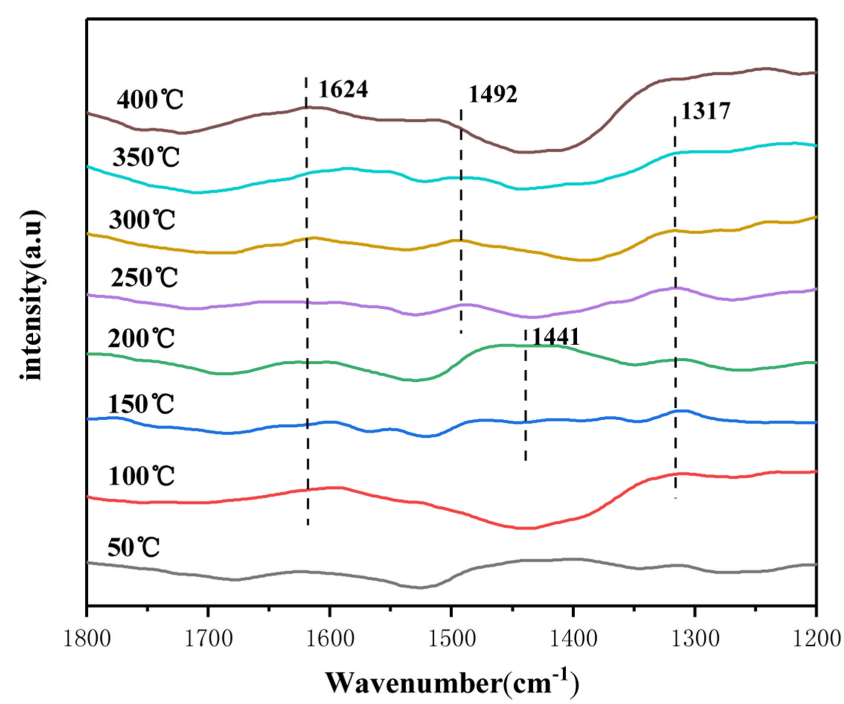

(a)

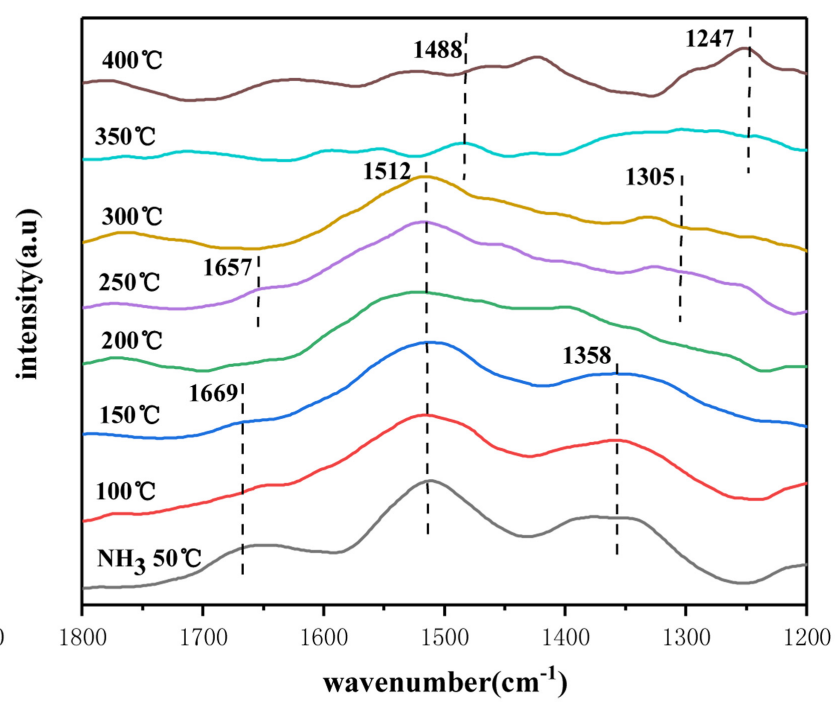

(b)

Figure 9. In-situ infrared spectra of $\mathrm{NH}_{3}$ adsorbed species on the catalyst surface under different temperature conditions. (a) $(\mathrm{Ce}, \mathrm{La}) \mathrm{CO}_{3} \mathrm{~F}$. (b) $\mathrm{Mn}(1 \mathrm{~mol} / \mathrm{L}) /(\mathrm{Ce}, \mathrm{La}) \mathrm{CO}_{3} \mathrm{~F}$.

at $1624 \mathrm{~cm}^{-1}$ belonged to $\mathrm{NH}_{2}$, an intermediate product of the dehydrogenation reaction of the $\mathrm{NH}_{3}$ species at the Lewis acidic site [43]. The absorption peak at $1317 \mathrm{~cm}^{-1}$ belonged to the $\mathrm{NH}_{4}^{+}$species at the Brønsted acidic site [46], so it can be assumed that the Brønsted/Lewis acidic site is involved in the reaction throughout the temperature interval. It is noteworthy that in the range of $150^{\circ} \mathrm{C}$ $200^{\circ} \mathrm{C}$, an infrared absorption peak appeared on the catalyst surface at 1441 $\mathrm{cm}^{-1}$, where the absorption peak belonged to the $\mathrm{NH}_{4}^{+}$species on the Brønsted acidic site [39], which indicated that more acidic sites were involved in the reaction in the range of $150^{\circ} \mathrm{C}-200^{\circ} \mathrm{C}$, with the Brønsted acidic site being the main acidic site, which favoured the catalytic reaction, which is consistent with the activity test results. As the temperature increased, the absorption peak at $1441 \mathrm{~cm}^{-1}$ was shifted to $1492 \mathrm{~cm}^{-1}$ and the intensity of the absorption peak was weakened, resulting in a decrease in denitrification efficiency. Overall, it appears that the (Ce,La) $\mathrm{CO}_{3} \mathrm{~F}$ catalyst has a weak peak intensity throughout the reaction temperature range, which indicated that this catalyst has a poor adsorption capacity for $\mathrm{NH}_{3}$, which is the reason for the low denitrification efficiency.

Figure 9(b) showed the variation of the thermal stability of the $\mathrm{Mn} /(\mathrm{Ce}, \mathrm{La}) \mathrm{CO}_{3} \mathrm{~F}$ catalyst for $\mathrm{NH}_{3}$ adsorbed species in the interval $50^{\circ} \mathrm{C}-400^{\circ} \mathrm{C}$. From Figure 9 (b), it can be observed that a strong IR absorption peak at $1512 \mathrm{~cm}^{-1}$ appears on the catalyst surface in the temperature range of $50^{\circ} \mathrm{C}-300^{\circ} \mathrm{C}$. The absorption peak here is attributed to the amide $\left(-\mathrm{NH}_{2}\right)$ species produced by the dehydrogenation reaction of $\mathrm{NH}_{4}^{+}$species adsorbed on the Brønsted acidic site, in the temperature interval of $50^{\circ} \mathrm{C}-300^{\circ} \mathrm{C}$, the $\mathrm{Br} \varnothing$ nsted acidic sites play a major role, which also indicated that the manganese nitrate solution could provide more Brønsted acidic sites for the catalyst. It can also be observed that within the low temperature section $\left(50^{\circ} \mathrm{C}-150^{\circ} \mathrm{C}\right)$, infrared absorption peaks appear on the catalyst surface at $1669 \mathrm{~cm}^{-1}$ and $1358 \mathrm{~cm}^{-1}$, with the absorption peak at $1669 \mathrm{~cm}^{-1}$ be- 
longed to the $\mathrm{NH}_{4}^{+}$species on the Brønsted acidic site [44] and the absorption peak at $1358 \mathrm{~cm}^{-1}$ belonged to the deformation vibration of the $\mathrm{N}-\mathrm{H}$ bond on the Brønsted acidic site. The Lewis acidic site was not detected throughout the low temperature section, which indicated that the Brønsted acidic site occupied the main active site in the low temperature section. With increasing temperature, only the amide $\left(-\mathrm{NH}_{2}\right)$ species at $1512 \mathrm{~cm}^{-1}$ was stable in the range of $200^{\circ} \mathrm{C}$ $300^{\circ} \mathrm{C}$. All other absorption peaks belonged to the Brønsted acidic site underwent pyrolysis and desorption, but were accompanied by the appearance of some new absorption peaks. The absorption peak at $1657 \mathrm{~cm}^{-1}$ belonged to the intermediate product $-\mathrm{NH}_{2}$ species after dehydrogenation of $\mathrm{NH}_{3}$, and the absorption peak at $1305 \mathrm{~cm}^{-1}$ belonged to the $\mathrm{eNH}_{2}$ species generated by the dehydrogenation reaction of the activated $\mathrm{NH}_{3}$ species [39]. According to the denitrification activity test results, it can be obtained that the denitrification rate decreases to a certain extent at $200^{\circ} \mathrm{C}$, and then there is a substantial recovery at $250^{\circ} \mathrm{C}$. From Figure $9(\mathrm{~b})$, it can be seen that the $\mathrm{NH}_{4}^{+}$species at $1358 \mathrm{~cm}^{-1}$ and $1669 \mathrm{~cm}^{-1}$ decompose when the reaction temperature reaches $200^{\circ} \mathrm{C}$, and only the amide $\left(-\mathrm{NH}_{2}\right)$ species at $1512 \mathrm{~cm}^{-1}$ is involved in the reaction on the catalyst surface, so causing such a phenomenon to occur.

The process of $\mathrm{NO}+\mathrm{O}_{2}$ species adsorption and activation on the catalyst surface under different temperature conditions was investigated by in situ infrared spectroscopy to discuss the forms and changes of NOx species present on the catalyst surface under different temperature conditions. Figure 10(a) showed the infrared variation spectrum of thermal stability of $\mathrm{NO}+\mathrm{O}_{2}$ adsorbed species on the $(\mathrm{Ce}, \mathrm{La}) \mathrm{CO}_{3} \mathrm{~F}$ catalyst in the temperature interval of $50^{\circ} \mathrm{C}-400^{\circ} \mathrm{C}$. Firstly, it can be observed that only one IR absorption peak appears on the catalyst surface at $1438 \mathrm{~cm}^{-1}$ in the temperature interval $50^{\circ} \mathrm{C}-100^{\circ} \mathrm{C}$. The absorption peak here can be attributed to the monodentate nitrate species [51], but as the temperature increases, the monodentate species decomposes, so it only occupies the

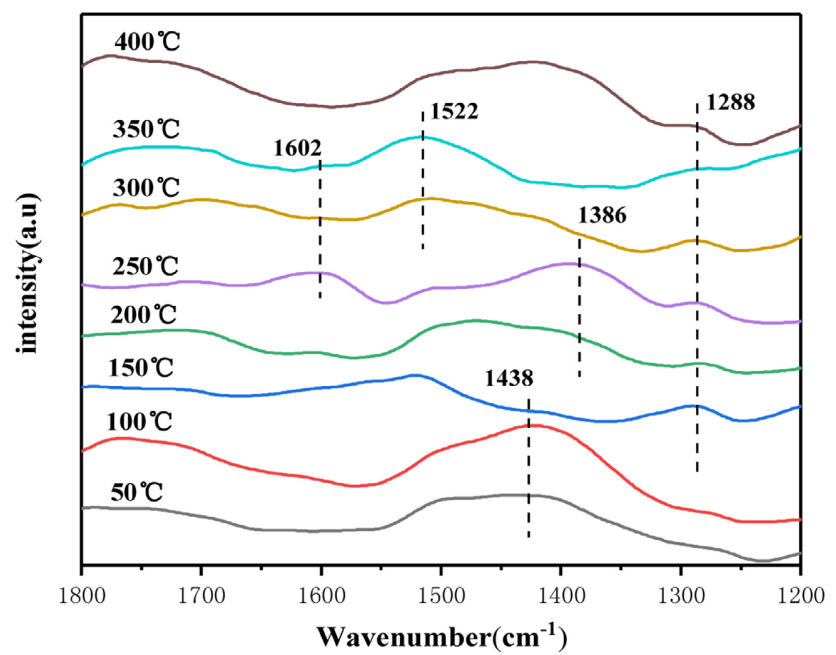

(a)

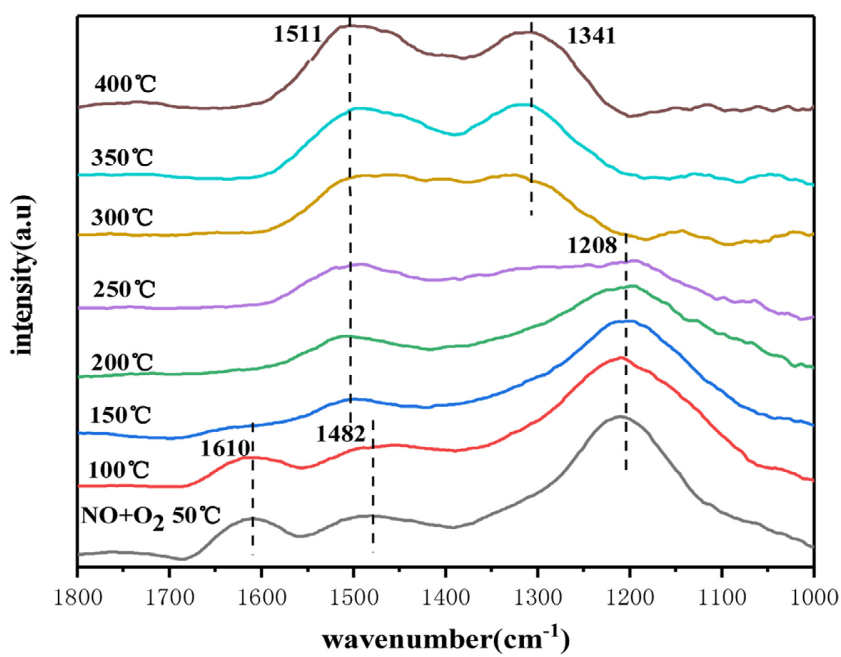

(b)

Figure 10. In-situ infrared spectra of $\mathrm{NO}+\mathrm{O}_{2}$ adsorbed species on the catalyst surface under different temperature conditions. (a) $(\mathrm{Ce}, \mathrm{La}) \mathrm{CO}_{3} \mathrm{~F}$. (b) $\mathrm{Mn}(1 \mathrm{~mol} / \mathrm{L}) /(\mathrm{Ce}, \mathrm{La}) \mathrm{CO}_{3} \mathrm{~F}$. 
active site in the low temperature section. In the temperature interval of $150^{\circ} \mathrm{C}$ $250^{\circ} \mathrm{C}$, IR absorption peaks appeared on the catalyst surface at $1288 \mathrm{~cm}^{-1}, 1386$ $\mathrm{cm}^{-1}$ and $1602 \mathrm{~cm}^{-1}$. The absorption peaks at $1288 \mathrm{~cm}^{-1}$ and $1386 \mathrm{~cm}^{-1}$ both belonged to monodentate nitrate species [43] [49], and the IR absorption peak at $1602 \mathrm{~cm}^{-1}$ belonged to the Ce-O-Ce site on the $\mathrm{NO}_{2}$ species [38]. It is clear that only some of the monodentate nitrate species are relatively more stable in this temperature interval, occupying the active sites in the middle and high temperature bands. As the temperature increased, the $\mathrm{NO}_{2}$ species disappeared and a new monodentate nitrate species appeared at $1522 \mathrm{~cm}^{-1}$. Throughout the temperature interval, the nitrate species produced by adsorbed NO were dominated by monodentate nitrate, but the adsorption and its instability and susceptibility to decomposition by temperature contributed to the poor denitrification activity.

Figure 10 (b) showed the IR variation spectrum of the thermal stability of the $\mathrm{NO}+\mathrm{O}_{2}$ adsorbed species of the $\mathrm{Mn} /(\mathrm{Ce}, \mathrm{La}) \mathrm{CO}_{3} \mathrm{~F}$ catalyst in the interval of $50^{\circ} \mathrm{C}-$ $400^{\circ} \mathrm{C}$. As can be seen from Figure 10 (b), strong IR absorption peaks appear on the catalyst surface at $1208 \mathrm{~cm}^{-1}, 1482 \mathrm{~cm}^{-1}$ and $1610 \mathrm{~cm}^{-1}$ in the temperature interval of $50^{\circ} \mathrm{C}-250^{\circ} \mathrm{C}$. The absorption peaks at $1208 \mathrm{~cm}^{-1}$ and $1482 \mathrm{~cm}^{-1}$ belonged to the monodentate nitrate species formed on the Mn-O-Ce site [51]. The absorption peak at $1610 \mathrm{~cm}^{-1}$ belonged to $\mathrm{NO}_{2}$ species adsorbed on the catalyst surface [45]. It has been reported in the literature that $\mathrm{NO}_{2}$ species are important intermediates in the fast SCR reaction under low temperature conditions and also an important factor in improving the catalytic performance of the catalyst [54] [55] [56]. As the temperature continues to rise, the $\mathrm{NO}_{2}$ species disappears, which indicates that it is less stable and prone to decomposition, while the monodentate nitrate species is relatively more stable. The absorption peak at $1511 \mathrm{~cm}^{-1}$ is a monodentate species formed by the shift of the absorption peak at $1482 \mathrm{~cm}^{-1}$. The shift and increase in peak intensity is due to the gradual formation of more monodentate species on the catalyst surface, so that until $250^{\circ} \mathrm{C}$ the monodentate species occupies the main active site in the reaction. As the temperature continues to increase, the peak of the monodentate nitrate species gradually disappears and a peak belonged to the bidentate nitrate species appears at $1341 \mathrm{~cm}^{-1}$. The high temperature inactivation may be due to the fact that $\mathrm{Mn}^{3+}$ and $\mathrm{Ce}^{3+}$ only bond with the monodentate nitrate species to form $\mathrm{O}-\mathrm{Mn}^{3+}-\mathrm{O}-\mathrm{NO}$ and $\mathrm{O}-\mathrm{Ce}^{3+}-\mathrm{O}-\mathrm{NO}$ intermediates to participate in the reaction, and not with the other nitrate species. Compared to the synthetic (Ce,La) $\mathrm{CO}_{3} \mathrm{~F}$ catalyst, the loading of $\mathrm{Mn}$ resulted in the formation of a greater number of monodentate nitrates and a very significant increase in the peak intensity of the absorption peaks, which in turn bound transition metal ions to participate in the reaction. There is a reduction in the number of nitrate species on the catalyst surface, but an increase in the absorption peak intensity of the monodentate species, which occupies the active site throughout the denitration temperature band.

To further investigate the $\mathrm{NH}_{3}$-SCR reaction mechanism of the catalyst, in-situ IR spectroscopy of the catalyst was carried out under different reaction conditions at the optimum denitrification temperature. Figure 11(a) showed the 


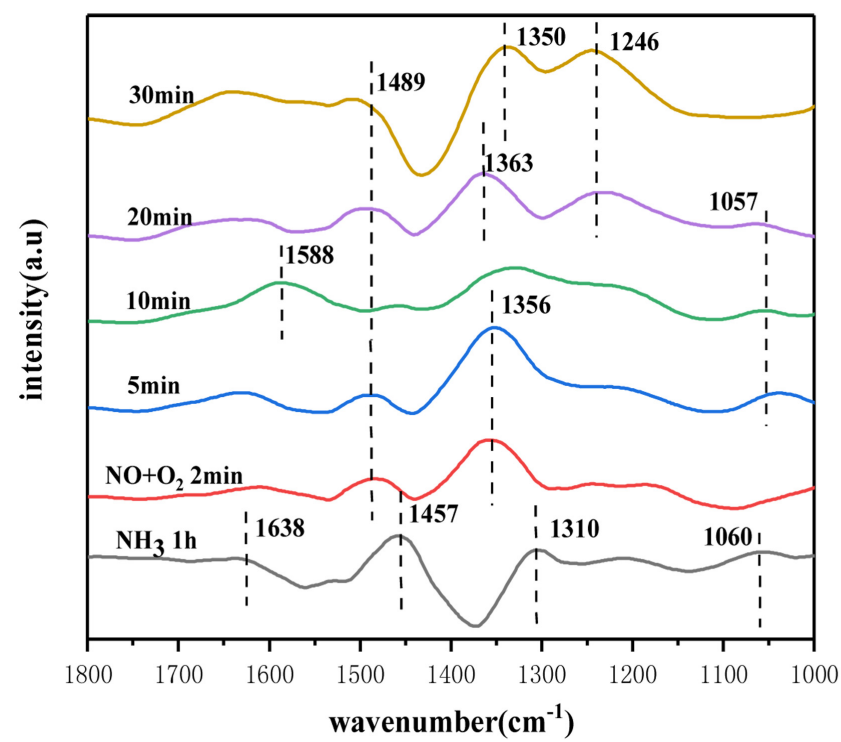

(a)

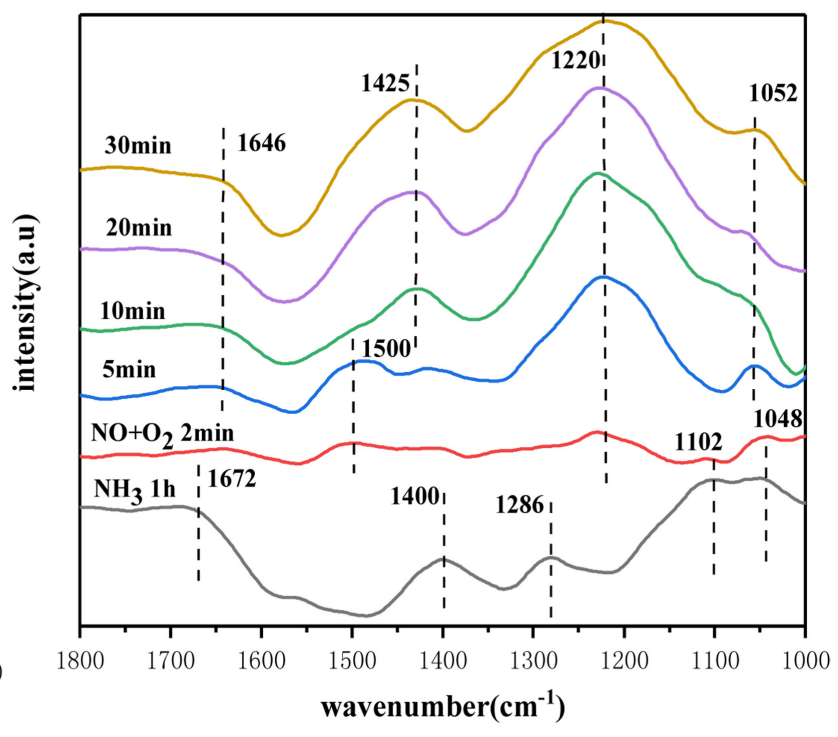

(b)

Figure 11. In-situ infrared spectra of the reaction of $\mathrm{NH}_{3}$ pre-adsorbed species on the catalyst surface under the optimal reaction temperature.

in situ IR spectra of the reaction of $\mathrm{NO}+\mathrm{O}_{2}$ on the surface of the $(\mathrm{Ce}, \mathrm{La}) \mathrm{CO}_{3} \mathrm{~F}$ catalyst with preadsorbed $\mathrm{NH}_{3}$ species at $200^{\circ} \mathrm{C}$. The $\mathrm{NH}_{3}$ gas was first introduced into the IR reaction cell containing the catalyst for $60 \mathrm{~min}$, before which $\mathrm{N}_{2}$ was used as a supplementary gas to pretreat the catalyst at $200^{\circ} \mathrm{C}$ for $30 \mathrm{~min}$, then the $\mathrm{NH}_{3}$ gas was stopped and purged with $\mathrm{N}_{2}$ for $10 \mathrm{~min}$. The changes in the IR spectrum of the catalyst surface were observed at $200^{\circ} \mathrm{C}$. After first adsorption of $\mathrm{NH}_{3}$ for $1 \mathrm{~h}$, it can be found that more stable $\mathrm{NH}_{3}$ adsorption species appear on the catalyst surface at $1638 \mathrm{~cm}^{-1}, 1457 \mathrm{~cm}^{-1}, 1310 \mathrm{~cm}^{-1}$ and $1060 \mathrm{~cm}^{-1}$. The IR absorption peaks at $1638 \mathrm{~cm}^{-1}$ and $1060 \mathrm{~cm}^{-1}$ are attributed to $\mathrm{NH}_{3}$ species on the Lewis acidic site [57], and the IR absorption peaks at $1457 \mathrm{~cm}^{-1}$ and $1310 \mathrm{~cm}^{-1}$ are attributed to $\mathrm{NH}_{4}^{+}$species on the Brønsted acidic site. $\mathrm{NH}_{3}$ was switched off and $\mathrm{NO}+\mathrm{O}_{2}$ gas was then introduced into the reaction cell. When $\mathrm{NO}+\mathrm{O}_{2}$ was introduced for 2 min, the $\mathrm{NH}_{4}^{+}$species on the Brønsted acidic sites at $1457 \mathrm{~cm}^{-1}$ and $1310 \mathrm{~cm}^{-1}$ and the $\mathrm{NH}_{3}$ species belonging to the Lewis acidic site at $1060 \mathrm{~cm}^{-1}$ disappeared rapidly, and only the absorption peak at $1638 \mathrm{~cm}^{-1}$ was present, which indicated that the $\mathrm{NH}_{3} / \mathrm{NH}_{4}^{+}$species could react rapidly with NO here. The E- $\mathrm{R}$ reaction mechanism exists on the surface of the (Ce,La) $\mathrm{CO}_{3} \mathrm{~F}$ catalyst and the main reacting species are $\mathrm{NH}_{3} / \mathrm{NH}_{4}^{+}$species and $\mathrm{NO}$ species. With increasing $\mathrm{NO}+\mathrm{O}_{2}$ influx time, the infrared absorption peaks of NO adsorbed species appear at $1489 \mathrm{~cm}^{-1}$ and $1356 \mathrm{~cm}^{-1}$ on the catalyst surface at $5 \mathrm{~min}$, both of which are monodentate nitrate species. At $10 \mathrm{~min}$ the absorption peaks of the monodentate nitrate species weakened, and according to the IR profiles of the $(\mathrm{Ce}, \mathrm{La}) \mathrm{CO}_{3} \mathrm{~F}$ catalysts for $\mathrm{NO}+\mathrm{O}_{2}$ adsorption over time, the monodentate nitrate species were very stable over time, so the weakening of the monodentate nitrate here was probably due to the reaction with the incomplete- 
ly reacted $\mathrm{NH}_{3} / \mathrm{NH}_{4}^{+}$species, which suggested that the $\mathrm{L}-\mathrm{H}$ mechanism was also present here, with the main reacting species were $\mathrm{NH}_{3} / \mathrm{NH}_{4}^{+}$species and $\mathrm{O}-\mathrm{Ce}^{3+}$-O-NO species. With increasing time, many new spectral bands of nitrate species appeared on the catalyst surface. The IR absorption peaks at $1363 \mathrm{~cm}^{-1}$ and $1350 \mathrm{~cm}^{-1}$ belong to monodentate nitrate species adsorbed on the Ce-O-Ce sites on the catalyst surface, and the IR absorption peaks at $1588 \mathrm{~cm}^{-1}$ and 1246 $\mathrm{cm}^{-1}$ belonged to bridged nitrate species [58]. the peak at $1057 \mathrm{~cm}^{-1}$ belonged to the linked secondary nitrate species $\left[-\left(\mathrm{N}_{2} \mathrm{O}_{2}\right)^{2-}\right][59]$ [60].

Figure 11(b) showed the in situ IR spectra of the reaction of $\mathrm{NO}+\mathrm{O}_{2}$ on the surface of the $\mathrm{Mn} /(\mathrm{Ce}, \mathrm{La}) \mathrm{CO}_{3} \mathrm{~F}$ catalyst with preadsorbed $\mathrm{NH}_{3}$ species at $250^{\circ} \mathrm{C}$. When $\mathrm{NH}_{3}$ was introduced into the reaction cell system for $60 \mathrm{~min}$ at $250^{\circ} \mathrm{C}$, IR absorption peaks could be observed on the catalyst surface at $1672 \mathrm{~cm}^{-1}, 1102$ $\mathrm{cm}^{-1}, 1400 \mathrm{~cm}^{-1}, 1286 \mathrm{~cm}^{-1}$ and $1048 \mathrm{~cm}^{-1}$, with the absorption peaks at 1672 $\mathrm{cm}^{-1}$ and $1048 \mathrm{~cm}^{-1}$ belonged to the $\mathrm{NH}_{3}$ species at the Lewis acid site. The absorption peaks at $1102 \mathrm{~cm}^{-1}, 1400 \mathrm{~cm}^{-1}$ belonged to the $\mathrm{NH}_{4}^{+}$species at the Brønsted acid position and the absorption peak at $1286 \mathrm{~cm}^{-1}$ belonged to the e- $\mathrm{NH}_{2}$ species generated by $\mathrm{NH}_{4}^{+}$dehydrogenation. With the passage of $\mathrm{NO}+\mathrm{O}_{2}$, the $\mathrm{NH}_{3}$ adsorbed species all disappeared at $2 \mathrm{~min}$, which indicated that $\mathrm{NH}_{3} / \mathrm{NH}_{4}^{+} / \mathrm{e}-\mathrm{NH}_{2}$ species can react with $\mathrm{NO}$ very quickly, so this catalyst surface follows the E- $\mathrm{R}$ mechanism. As the $\mathrm{NO}+\mathrm{O}_{2}$ pass time increased, nitrate species appeared on the $\mathrm{Mn} /(\mathrm{Ce}, \mathrm{La}) \mathrm{CO}_{3} \mathrm{~F}$ catalyst surface at $5 \mathrm{~min}$ pass, with a bidentate nitrate species $\left(1646 \mathrm{~cm}^{-1}\right)$, a monodentate nitrate species on the Mn-O-Ce site or the Ce-O-Ce site $\left(1220 \mathrm{~cm}^{-1}\right)$, even a secondary nitrate $\left[-\left(\mathrm{N}_{2} \mathrm{O}_{2}\right)^{2-}\right](1052$ $\left.\mathrm{cm}^{-1}\right)$, and monodentate nitrate species $\left(1500 \mathrm{~cm}^{-1}, 1425 \mathrm{~cm}^{-1}\right)$, but the disappearance of the absorption peak at $1500 \mathrm{~cm}^{-1}$ at $10 \mathrm{~min}$ was not due to a reaction with the $\mathrm{NH}_{3}$ adsorbed species, but to the production of a large number of monodentate nitrate species causing the absorption peak at $1500 \mathrm{~cm}^{-1}$ to be shifted to $1425 \mathrm{~cm}^{-1}$. This suggested that the $\mathrm{Mn} /(\mathrm{Ce}, \mathrm{La}) \mathrm{CO}_{3} \mathrm{~F}$ catalyst followed the E- $\mathrm{R}$ mechanism at $250^{\circ} \mathrm{C}$ with $\mathrm{NH}_{3} / \mathrm{NH}_{4}^{+} / \mathrm{e}-\mathrm{NH}_{2}$ and $\mathrm{NO}$ as the reacting species.

Figure 12 showed the in-situ IR spectra of the reaction of $\mathrm{NH}_{3}$ with pre-adsorbed $\mathrm{NO}+\mathrm{O}_{2}$ species for both catalysts at optimum denitration temperature conditions. Figure 12(a) showed the transient in-situ IR spectrum of the (Ce, $\mathrm{La}) \mathrm{CO}_{3} \mathrm{~F}$ catalyst at $200^{\circ} \mathrm{C}$ temperature conditions. When $\mathrm{NO}+\mathrm{O}_{2}$ was introduced into the reaction cell system for $60 \mathrm{~min}$, distinct IR absorption peaks appeared on the catalyst surface at $1618 \mathrm{~cm}^{-1}, 1489 \mathrm{~cm}^{-1}, 1340 \mathrm{~cm}^{-1}$ and 1252 $\mathrm{cm}^{-1}$, with the absorption peaks at $1618 \mathrm{~cm}^{-1}$ attributed to $\mathrm{NO}_{2}$ species (nitro or $\mathrm{NO}_{2}$ molecules) adsorbed on the Ce-O-Ce sites. Monodentate nitrate species $\left(1489 \mathrm{~cm}^{-1}\right)$, bidentate nitrate species $\left(1340 \mathrm{~cm}^{-1}\right)$, and bridged nitrate species $\left(1340 \mathrm{~cm}^{-1}\right)$ were also present, all of which were already present in a stable state on the catalyst surface. Turning off $\mathrm{NO}+\mathrm{O}_{2}, \mathrm{NH}_{3}$ gas was then passed into the reaction cell. With the introduction of $\mathrm{NH}_{3}$, it was observed that at $2 \mathrm{~min}$ the nitrate species generated on the surface of the $(\mathrm{Ce}, \mathrm{La}) \mathrm{CO}_{3} \mathrm{~F}$ catalyst disappeared and only the bridged nitrate species were present, but at 5 min they also participated in the reaction, which indicated that the $\mathrm{NO}_{2}$ species, monodentate nitrate 


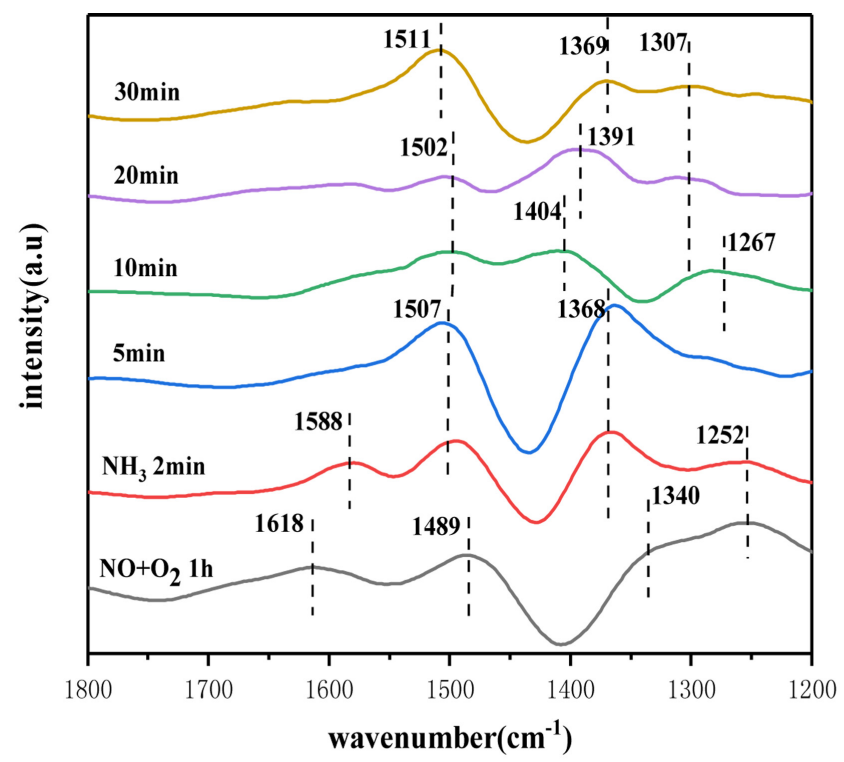

(a)

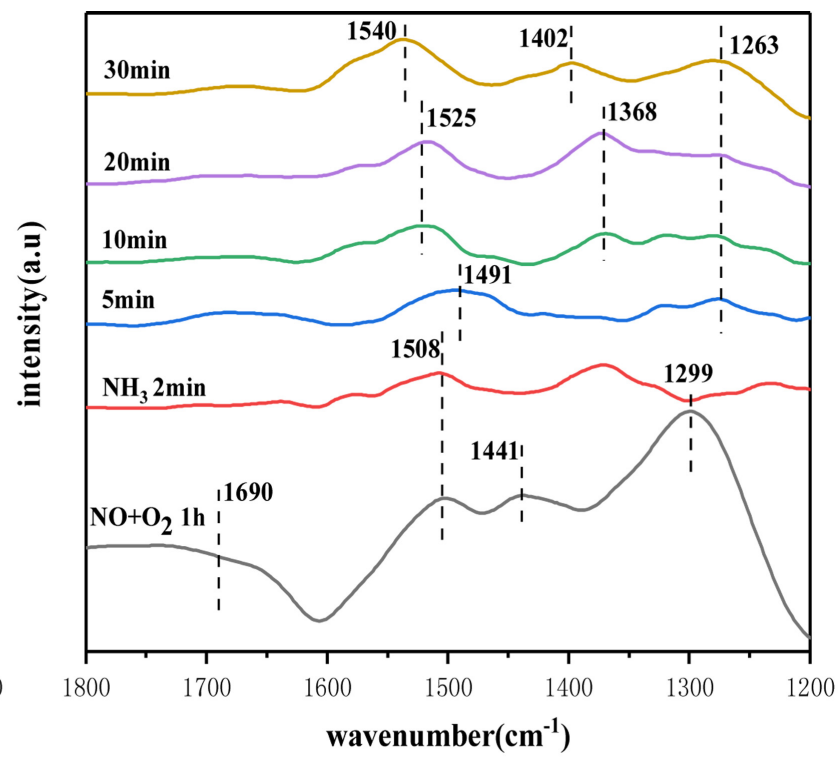

(b)

Figure 12. In-situ infrared spectra of the reaction of $\mathrm{NO}+\mathrm{O}_{2}$ pre-adsorbed species on the catalyst surface under the optimal reaction temperature. (a) $(\mathrm{Ce}, \mathrm{La}) \mathrm{CO}_{3} \mathrm{~F}$. (b) $\mathrm{Mn}(1 \mathrm{~mol} / \mathrm{L}) /(\mathrm{Ce}, \mathrm{La}) \mathrm{CO}_{3} \mathrm{~F}$.

and bridged nitrate species were involved in the reaction with the $\mathrm{NH}_{3}$ adsorbed species. With increased $\mathrm{NH}_{3}$ passage time, $\mathrm{NH}_{4}^{+}$species belonging to adsorbed on Brønsted acidic sites $\left(1404 \mathrm{~cm}^{-1}, 1369 \mathrm{~cm}^{-1}, 1368 \mathrm{~cm}^{-1}, 1391 \mathrm{~cm}^{-1}\right)$ and $\mathrm{NH}_{3}$ species belonging to Lewis acidic sites $\left(1588 \mathrm{~cm}^{-1}, 1307 \mathrm{~cm}^{-1}, 1267 \mathrm{~cm}^{-1}\right)$ and amide species $-\mathrm{NH}_{2}\left(1507 \mathrm{~cm}^{-1}, 1502 \mathrm{~cm}^{-1}, 1511 \mathrm{~cm}^{-1}\right)$ appeared on the catalyst surface, and the amide species $-\mathrm{NH}_{2}\left(1507 \mathrm{~cm}^{-1}, 1502 \mathrm{~cm}^{-1}, 1511 \mathrm{~cm}^{-1}\right)$, which suggested that an L-H mechanism also exists on the surface of the (Ce, La) $\mathrm{CO}_{3} \mathrm{~F}$ catalyst. The $\mathrm{NH}_{3}$ species on the Lewis acidic site are less stable and prone to decomposition as can be seen from the graph. The absorption peaks of the monodentate nitrate species are the most intense among the adsorbed species of $\mathrm{NO}$, so the main reactive species for the L-H mechanism are the $\mathrm{NH}_{4}^{+}$species on the Brønsted acidic site and the monodentate nitrate species bound to $\mathrm{Ce}^{3+}$.

Figure 12(b) showed the in situ IR spectra of the reaction of $\mathrm{NH}_{3}$ on the surface of the $\mathrm{Mn} /(\mathrm{Ce}, \mathrm{La}) \mathrm{CO}_{3} \mathrm{~F}$ catalyst with pre-adsorbed $\mathrm{NO}+\mathrm{O}_{2}$ species at $250^{\circ} \mathrm{C}$. When $\mathrm{NO}+\mathrm{O}_{2}$ was passed into the reaction cell system for $60 \mathrm{~min}$ at $250^{\circ} \mathrm{C}$, infrared absorption peaks could be observed on the catalyst surface at $1690 \mathrm{~cm}^{-1}$, $1508 \mathrm{~cm}^{-1}, 1441 \mathrm{~cm}^{-1}$ and $1299 \mathrm{~cm}^{-1}$, which belonged to the monodentate nitrate species $\left(1508 \mathrm{~cm}^{-1}, 1299 \mathrm{~cm}^{-1}\right)$, the bidentate nitrate species $\left(1690 \mathrm{~cm}^{-1}\right)$ and the trans $-\mathrm{N}_{2} \mathrm{O}_{4}$ cis $-\mathrm{N}_{2} \mathrm{O}_{2}$ species $\left(1441 \mathrm{~cm}^{-1}\right)$, which decomposes $\mathrm{NO}$ due to the reduction of $\mathrm{NO}_{2}$ by $\mathrm{Ce}^{3+}$. When $\mathrm{NH}_{3}$ was introduced, the absorption peaks of monodentate as well as bidentate nitrate species disappeared at $2 \mathrm{~min}$, here in reaction with $\mathrm{NH}_{3}$ adsorbed species, so that an L-H mechanism also existed on the $\mathrm{Mn} /(\mathrm{Ce}, \mathrm{La}) \mathrm{CO}_{3} \mathrm{~F}$ catalyst surface. With the passage of $\mathrm{NH}_{3}, \mathrm{NH}_{4}^{+}$species belonged to the Brønsted acidic site $\left(1402 \mathrm{~cm}^{-1}, 1491 \mathrm{~cm}^{-1}, 1525 \mathrm{~cm}^{-1}, 1508\right.$ $\left.\mathrm{cm}^{-1}, 1540 \mathrm{~cm}^{-1}\right)$ and $\mathrm{NH}_{3}$ species belonging to the Lewis acidic site $\left(1368 \mathrm{~cm}^{-1}\right.$, 
$1263 \mathrm{~cm}^{-1}$ ) appear on the catalyst surface. It can be clearly seen that the Brønsted acidic sites on the catalyst surface are the most abundant and the NO adsorption species have the highest intensity of the monodentate nitrate absorption peak, so the main reactive species for the $\mathrm{L}-\mathrm{H}$ mechanism are the $\mathrm{NH}_{4}^{+}$species and the $\mathrm{O}-\mathrm{Ce}^{3+}-\mathrm{O}-\mathrm{NO}$ and $\mathrm{O}-\mathrm{Mn}^{3+}-\mathrm{O}-\mathrm{NO}$ species.

The IR spectrum of the (Ce,La) $\mathrm{CO}_{3} \mathrm{~F}$ catalyst reveals E- $\mathrm{R}$ mechanism and $\mathrm{L}-\mathrm{H}$ mechanism at an optimum denitrification temperature of $200^{\circ} \mathrm{C}$. The reactive species in the $\mathrm{L}-\mathrm{H}$ mechanism are $\mathrm{NH}_{4}^{+}$species adsorbed on the Brønsted acidic site and monodentate nitrate species bonded to $\mathrm{Ce}^{3+}$.

The reaction process of the $\mathrm{L}-\mathrm{H}$ mechanism on the surface of the $(\mathrm{Ce}, \mathrm{La}) \mathrm{CO}_{3} \mathrm{~F}$ catalyst is as follows.

$$
\begin{gathered}
\mathrm{O}_{2}+2^{*} \rightarrow 2 \mathrm{O}^{-*} \quad(* \text { NO adsorption sites on catalyst surfaces }) \\
\left.\mathrm{NO}+\mathrm{O}_{2^{-}} *+\mathrm{Ce}^{4+}=\mathrm{O} \rightarrow \mathrm{O}-\mathrm{NO}-\mathrm{O}-\mathrm{Ce}^{3+} \quad \text { (monodentate nitrate }\right) \\
\mathrm{NH}_{3}(\mathrm{~g}) \rightarrow \mathrm{NH}_{4}^{+}(\mathrm{a})(\text { Brønsted }) \\
\mathrm{Ce}^{4+}-\mathrm{O}^{-}+\mathrm{NH}_{4}^{+} \rightarrow \mathrm{Ce}^{4+}-\mathrm{O}^{-}-\mathrm{NH}_{3}+\mathrm{H}^{+} \rightarrow \mathrm{Ce}^{4+}-\mathrm{O}^{-}-\mathrm{NH}_{2}+2 \mathrm{H}^{+} \\
\mathrm{Ce}^{4+}-\mathrm{O}^{-}-\mathrm{NH}_{2}+\mathrm{O}-\mathrm{NO}-\mathrm{O}-\mathrm{Ce}^{3+} \rightarrow \mathrm{Ce}^{4+}-\mathrm{O}^{-}-\mathrm{NH}_{2}-\mathrm{O}-\mathrm{NO}-\mathrm{O}-\mathrm{Ce}^{3+} \\
\mathrm{Ce}^{4+}-\mathrm{O}^{-}-\mathrm{NH}_{2}-\mathrm{O}-\mathrm{NO}-\mathrm{O}-\mathrm{Ce}^{3+} \rightarrow \mathrm{Ce}^{4+}-\mathrm{O}^{-}-\mathrm{NH}_{2}-\mathrm{O}-\mathrm{NO}+\mathrm{O}=\mathrm{Ce}^{4+} \\
\mathrm{Ce}^{4+}-\mathrm{O}^{-}-\mathrm{NH}_{2}-\mathrm{O}-\mathrm{NO} \rightarrow \mathrm{N}_{2}+\mathrm{H}_{2} \mathrm{O}+\mathrm{Ce}^{4+}-\mathrm{O}^{-}
\end{gathered}
$$

$\mathrm{Mn} /(\mathrm{Ce}, \mathrm{La}) \mathrm{CO}_{3} \mathrm{~F}$ catalysts were subjected to E-R and $\mathrm{L}-\mathrm{H}$ mechanisms at $250^{\circ} \mathrm{C}$. After loading with the transition metal Mn, the number of Brønsted acidic sites on the catalyst surface was increased, enhancing the ability to adsorb $\mathrm{NH}_{3}$ on the catalyst surface. The number of nitrate species was relatively reduced, but the number and peak strength of monodentate nitrate increased, so that the main reacting species for the $\mathrm{L}-\mathrm{H}$ mechanism of the $\mathrm{Mn} /(\mathrm{Ce}, \mathrm{La}) \mathrm{CO}_{3} \mathrm{~F}$ catalyst were monodentate nitrate species bonded to the metal ions $\mathrm{M}^{\mathrm{n}+}\left(\mathrm{Ce}^{4+}\right.$, $\mathrm{Mn}^{4+}$ ) and $\mathrm{NH}_{4}^{+}$species adsorbed on the Brønsted acidic sites. The reactions proceeded as follows. The L-H mechanism was shown in Figure 13.

$$
\begin{gathered}
\mathrm{O}_{2}+2 * \rightarrow 2 \mathrm{O}^{-*}(* \text { Newly introduced } \mathrm{Mn} \text { provides } \mathrm{NO} \text { adsorption site) } \\
\mathrm{NO}+\mathrm{O}_{2^{-}} *+\mathrm{M}^{\mathrm{n}+}=\mathrm{O} \rightarrow \mathrm{O}-\mathrm{NO}-\mathrm{O}-\mathrm{M}^{(\mathrm{n}-1)+} \quad \text { (monodentate nitrate) } \\
\mathrm{NH}_{3}(\mathrm{~g}) \rightarrow \mathrm{NH}_{4}^{+}(\mathrm{a}) \quad(\text { Brønsted }) \\
\mathrm{Ce}^{4+}-\mathrm{NH}_{4}^{+}+2 \mathrm{O}^{-} \rightarrow \mathrm{Ce}^{4+}-\mathrm{NH}_{2}+2 \mathrm{OH}^{-} \quad(\mathrm{Brønsted}) \\
\mathrm{Ce}^{4+}-\mathrm{NH}_{2}+\mathrm{O}-\mathrm{NO}-\mathrm{O}-\mathrm{M}^{(\mathrm{n}-1)+} \rightarrow \mathrm{Ce}^{4+}-\mathrm{NH}_{2}-\mathrm{O}-\mathrm{NO}-\mathrm{O}-\mathrm{M}^{(\mathrm{n}-1)+} \\
\mathrm{Ce}^{4+}-\mathrm{NH}_{2}-\mathrm{O}-\mathrm{NO}-\mathrm{O}-\mathrm{M}^{(\mathrm{n}-1)+} \rightarrow \mathrm{Ce}^{4+}-\mathrm{NH}_{2}-\mathrm{O}-\mathrm{NO}+\mathrm{O}=\mathrm{M}^{\mathrm{n}+} \\
\mathrm{Ce}^{4+}-\mathrm{NH}_{2}-\mathrm{O}-\mathrm{NO} \rightarrow \mathrm{N}_{2}+\mathrm{H}_{2} \mathrm{O}+\mathrm{Ce}^{4+}-\mathrm{O}^{-}
\end{gathered}
$$

The E- $\mathrm{R}$ reaction mechanism is also present on the surface of the $(\mathrm{Ce}, \mathrm{La}) \mathrm{CO}_{3} \mathrm{~F}$ catalyst at $200^{\circ} \mathrm{C}$. The reacting species are $\mathrm{NO}$ and $\mathrm{NH}_{4}^{+}$species at the Brønsted acidic site on the catalyst surface, and the E-R mechanism reaction 


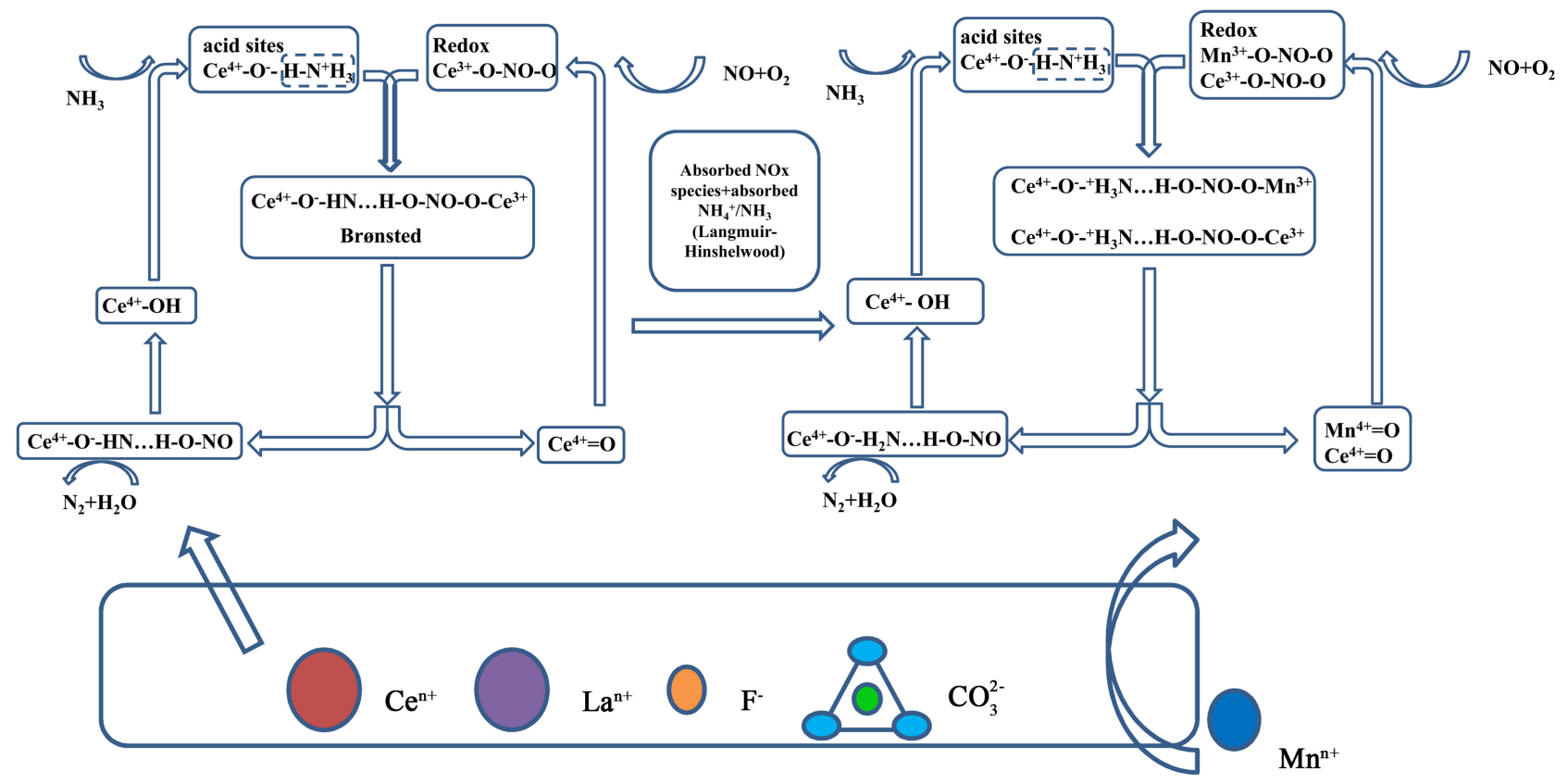

Figure 13. Schematic diagram of the L-H mechanism for the synthesis of (Ce,La) $\mathrm{CO}_{3} \mathrm{~F}$ and Mn-loaded catalysts.

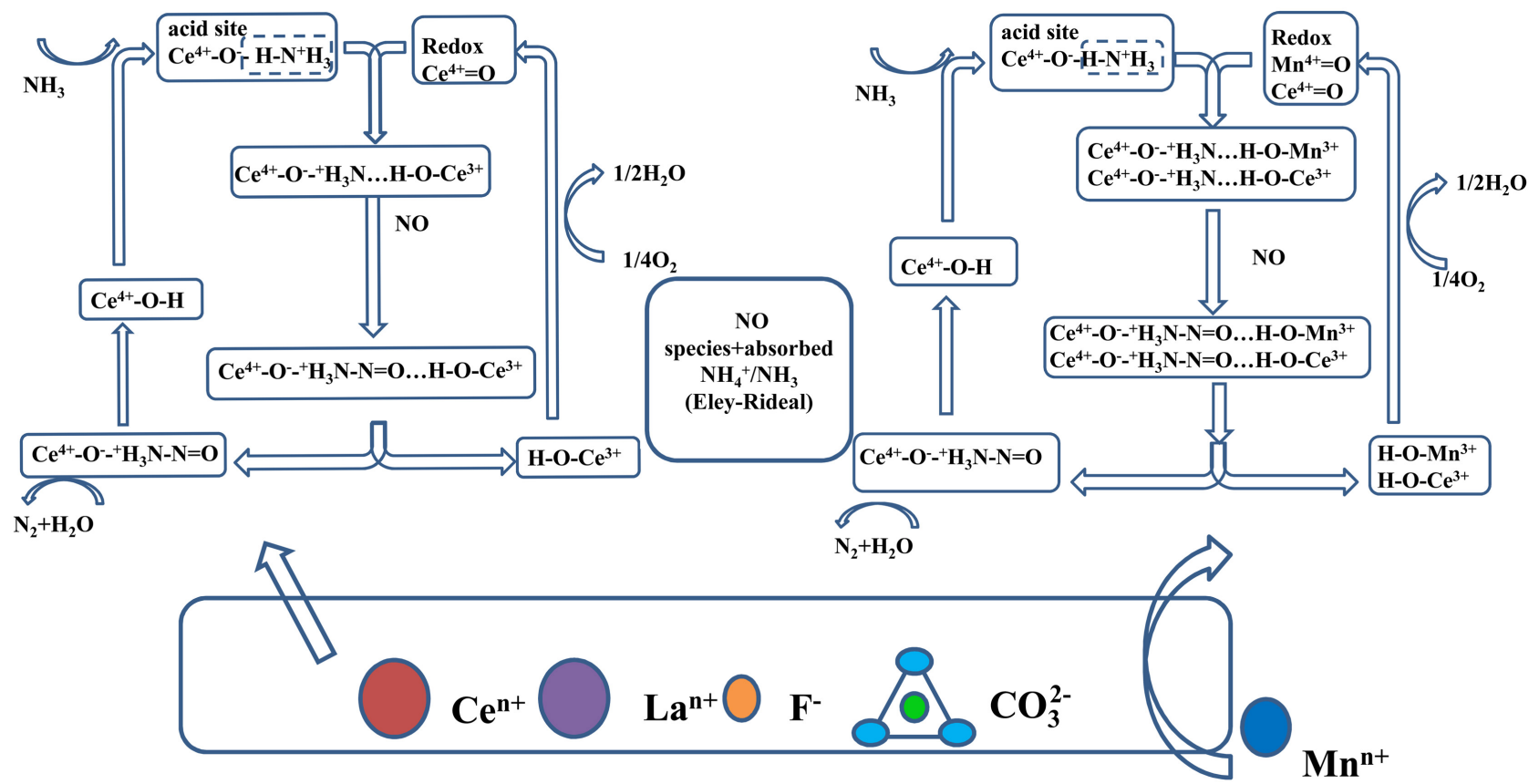

Figure 14. Schematic diagram of the E-R mechanism for the synthesis of (Ce,La) $\mathrm{CO}_{3} \mathrm{~F}$ and Mn-loaded catalysts.

proceeds as follows.

$$
\begin{gathered}
\mathrm{NH}_{3}(\mathrm{~g}) \rightarrow \mathrm{NH}_{4}^{+}(\mathrm{a}) \quad(\text { Brønstedacidic sites }) \\
\mathrm{Ce}^{4+}-\mathrm{O}-\mathrm{NH}_{4}^{+}+\mathrm{Ce}^{4+}=\mathrm{O} \rightarrow \mathrm{Ce}^{4+}-\mathrm{O}^{-}-\mathrm{NH}_{3}+\mathrm{Ce}^{3+}-\mathrm{OH} \quad(\text { Brønsted }) \\
\mathrm{Ce}^{4+}-\mathrm{O}^{-}-\mathrm{NH}_{3}^{+}-\mathrm{HO}-\mathrm{Ce}^{3+}+\mathrm{NO} \rightarrow \mathrm{Ce}^{4+}-\mathrm{O}^{-}-\mathrm{NH}_{3}^{+}-\mathrm{N}=\mathrm{O}-\mathrm{HO}-\mathrm{Ce}^{3+} \\
\mathrm{Ce}^{4+}-\mathrm{O}^{-}-\mathrm{NH}_{3}^{+}-\mathrm{N}=\mathrm{O}-\mathrm{HO}-\mathrm{Ce}^{3+} \rightarrow \mathrm{Ce}^{4+}-\mathrm{O}^{-}-\mathrm{NH}_{3}^{+}-\mathrm{N}-\mathrm{O}+\mathrm{HO}-\mathrm{Ce}^{3+}
\end{gathered}
$$




$$
\mathrm{Ce}^{4+}-\mathrm{O}^{-}-\mathrm{NH}_{3}^{+}-\mathrm{N}-\mathrm{O} \rightarrow \mathrm{N}_{2}+\mathrm{H}_{2} \mathrm{O}+\mathrm{Ce}^{4+}-\mathrm{OH}
$$

The $\mathrm{Mn} /(\mathrm{Ce}, \mathrm{La}) \mathrm{CO}_{3} \mathrm{~F}$ catalyst also has an E- $\mathrm{R}$ mechanism at $250^{\circ} \mathrm{C}$. The reacting species are mainly $\mathrm{NO}$ and $\mathrm{NH}_{4}^{+}$species adsorbed on the acidic sites of Brønsted. The E- $\mathrm{R}$ mechanism reaction process of the $\mathrm{Mn} /(\mathrm{Ce}, \mathrm{La}) \mathrm{CO}_{3} \mathrm{~F}$ catalyst is as follows, where $\mathrm{M}\left(\mathrm{Mn}^{4+}, \mathrm{Ce}^{4+}\right)$. The E-R mechanism was shown in Figure 14.

$$
\begin{gathered}
\mathrm{NH}_{3}(\mathrm{~g}) \rightarrow \mathrm{NH}_{4}^{+}(\mathrm{a}) \quad(\text { Brønsted }) \\
\mathrm{Ce}^{4+}-\mathrm{O}-\mathrm{NH}_{4}^{+}+\mathrm{M}^{\mathrm{n}+}=\mathrm{O} \rightarrow \mathrm{Ce}^{4+}-\mathrm{O}^{-}-\mathrm{NH}_{3}^{+}+\mathrm{M}^{(\mathrm{n}-1)+}-\mathrm{OH} \quad(\text { Brønsted }) \\
\mathrm{Ce}^{4+}-\mathrm{O}^{-}-\mathrm{NH}_{3}+\mathrm{NO} \rightarrow \mathrm{N}_{2}+\mathrm{H}_{2} \mathrm{O}+\mathrm{Ce}^{4+}-\mathrm{OH} \\
\mathrm{M}^{(\mathrm{n}-1)+}-\mathrm{OH} \rightarrow 1 / 4 \mathrm{O}_{2}+1 / 2 \mathrm{H}_{2} \mathrm{O}+\mathrm{M}^{\mathrm{n}+}=\mathrm{O}
\end{gathered}
$$

\section{Conclusion}

In accordance with the cerium-lanthanum ratio of fluorocerium ores in the mineralogy of the Baiyun Ebo process, pure substances such as $\mathrm{Ce}\left(\mathrm{NO}_{3}\right)_{3} \cdot 6 \mathrm{H}_{2} \mathrm{O}$, $\mathrm{La}\left(\mathrm{NO}_{3}\right)_{3} \cdot 6 \mathrm{H}_{2} \mathrm{O}$ were used to synthesize $(\mathrm{Ce}, \mathrm{La}) \mathrm{CO}_{3} \mathrm{~F}$ grains to simulate bastnaesite minerals by hydrothermal method, and used as $\mathrm{NH}_{3}$-SCR denitrification catalysts. After being roasted at a series of different temperatures, the catalyst surface produced a well-crystallised $\mathrm{Ce}_{7} \mathrm{O}_{12}$ species as the active component for denitrification. The activity results showed that the synthetic $(\mathrm{Ce}, \mathrm{La}) \mathrm{CO}_{3} \mathrm{~F}$ was roasted at $500^{\circ} \mathrm{C}$, and the $\mathrm{NOx}$ conversion was $27 \%$ at $200^{\circ} \mathrm{C}$. The $\mathrm{NH}_{3}-\mathrm{SCR}$ catalytic activity of the synthesised ( $\mathrm{Ce}, \mathrm{La}) \mathrm{CO}_{3} \mathrm{~F}$ was improved by loaded transition metal $\mathrm{Mn}$. The best catalyst was found to be produced by impregnating (Ce,La) $\mathrm{CO}_{3} \mathrm{~F}$ with $1 \mathrm{~mol} / \mathrm{L}$ manganese nitrate solution, with a NOx conversion of $80 \%$ at $250^{\circ} \mathrm{C}$. The physicochemical properties were analysed using XRD, BET, $\mathrm{H}_{2}$-TPR, $\mathrm{NH}_{3}$-TPD and XPS. The loading of $\mathrm{Mn}$ resulted in the appearance of numerous well-dispersed $\mathrm{MnOx}$ species on the catalyst surface, the dispersion of $\mathrm{Ce}_{7} \mathrm{O}_{12}$ species was also greatly enhanced, and the reduction in grain size indicated that $\mathrm{Mn}^{\mathrm{n}+}$ entered into the (Ce,La) $\mathrm{CO}_{3} \mathrm{~F}$ lattice causing lattice shrinkage. The number of acidic sites on the catalyst surface and the redox capacity were enhanced. The amount of $\mathrm{Ce}^{3+}$ in the catalyst was also enhanced by the introduction of $\mathrm{Mn}^{\mathrm{n}+}$, but the proportion of adsorbed oxygen decreased, which indicated that the introduction of $\mathrm{Mn}^{\mathrm{n}+}$ was detrimental to the increase in the proportion of adsorbed oxygen. The reaction mechanisms of the $(\mathrm{Ce}, \mathrm{La}) \mathrm{CO}_{3} \mathrm{~F}$ and $\mathrm{Mn} /(\mathrm{Ce}, \mathrm{La}) \mathrm{CO}_{3} \mathrm{~F}$ catalysts were investigated by in-situ Fourier transform infrared spectroscopy (FTIR), to provide theoretical guidance for the specific reaction pathways of bastnaesite in the $\mathrm{NH}_{3}$-SCR reaction. The results showed that catalysts followed both the E-R and L-H mechanisms throughout the reaction process. When loaded with $\mathrm{Mn}$, the main reactive species in the $\mathrm{L}-\mathrm{H}$ mechanism were the $\mathrm{NH}_{4}^{+}$(ad) species on the Brønsted acidic site and the O-Ce ${ }^{3+}-\mathrm{O}-\mathrm{NO}$, $\mathrm{O}-\mathrm{Mn}^{3+}-\mathrm{O}-\mathrm{NO}$ species. The main reactive species for the $\mathrm{E}-\mathrm{R}$ mechanism were $\mathrm{NH}_{3} / \mathrm{NH}_{4}^{+}$(ad) species on the Brønsted/Lewis acidic sites and NO. The $\mathrm{NH}_{4}^{+}$ 
(ad) species on the Brønsted acidic sites act as the main reactive $\mathrm{NH}_{3}(\mathrm{~g})$ adsorbing species, bonded to the $\mathrm{Ce}^{4+}$ in the carrier $(\mathrm{Ce}, \mathrm{La}) \mathrm{CO}_{3} \mathrm{~F}$ to participate in the acid cycle reaction. The introduction of $\mathrm{Mn}^{\mathrm{n}+}$ increases the number of Brønsted acidic sites on the catalyst surface, and acts as an adsorption site for NO, to react with NO to generate more monodentate nitrate species, to participate in the redox cycle reactions. The above results indicated that $\mathrm{Mn}^{\mathrm{n}+}$ and $(\mathrm{Ce}, \mathrm{La}) \mathrm{CO}_{3} \mathrm{~F}$ have a good mutual promotion effect, which makes the loaded catalyst have excellent performance, which provides a theoretical basis for the high value utilization of bastnaesite.

\section{Acknowledgements}

This study was financially supported by Natural Science Foundation of Inner Mongolia (Grant No. 2019ZD13, 2020BS05030), National Natural Science Foundation of China (Grant No. 51866013). Thanks for Start-up Funds for Talent Introduction and Scientific Research of Institutions in Inner Mongolia Autonomous Region.

\section{Conflicts of Interest}

The authors declare no conflicts of interest regarding the publication of this paper.

\section{References}

[1] Zhu, Z.H., Yang, Z.F., Wang, Q.W., Wang, Z.J. and Li, N. (2019) Research on Process Mineralogy of Bayan Obo Rare Earth Concentrate. Non-Ferrous Metals (Mineral Processing Part), No. 6, 1-4+22.

[2] Huang, S.H., Wang, Z.G., Zhang, Z.M. and He, S.Y. (1986) Experimental Study on the Formation Conditions of Bastnaesite. Acta Minera Sinica, No. 2, 61-66.

[3] Mohammed, N., Kabbashi, N., Alade, A., et al. (2018) Advancement in the Utilization of Biomass-Derived Heterogeneous Catalysts in Biodiesel Production. Green and Sustainable Chemistry, 8, 74-91. https://doi.org/10.4236/gsc.2018.81006

[4] Yao, X., Kong, T., Chen, L., et al. (2017) Enhanced Low-Temperature $\mathrm{NH}_{3}$-SCR Performance of $\mathrm{MnO}_{\mathrm{x}} / \mathrm{CeO}_{2}$ Catalysts by Optimal Solvent Effect. Applied Surface Science, 420, 407-415. https://doi.org/10.1016/j.apsusc.2017.05.156

[5] Gong, P.J., Xie, J.L., Fang, D., He, F., Li, F.X. and Qi, K. (2020) Enhancement of the $\mathrm{NH}_{3}$-SCR Property of Ce-Zr-Ti by Surface and Structure Modification with P. Applied Surface Science, 505, Article ID: 144641. https://doi.org/10.1016/j.apsusc.2019.144641

[6] Li, J., Han, Y.X., Zhu, Y.H. and Zhou, R.X. (2011) Purification of Hydrogen from Carbon Monoxide for Fuel Cell Application over Modified Mesoporous $\mathrm{CuO}-\mathrm{CeO}_{2}$ Catalysts. Applied Catalysis B, Environmental, 108-109, 72-80.

[7] Zhen, K.J. (2005) Fundamentals of Catalyst Action. Science Press, Beijing.

[8] Li, L.L. (2017) Preparation of Cerium-Based $\mathrm{NH}_{3}$-SCR Catalyst and Its Denitrification Performance. Nanjing University, Nanjing.

[9] Zhang, K., Ge, Y., Zhu, J., et al. (2019) Surface Characteristics and Catalytic Activity of Modified Rare Earth Concentrate for Low-Temperature Selective Catalytic Re- 
duction of $\mathrm{NO}_{x}$ with $\mathrm{NH}_{3}$. Materials Chemistry and Physics, 2019, Article ID: 122421. https://doi.org/10.1016/j.matchemphys.2019.122421

[10] Xie, S., Li, L., Jin, L., et al. (2019) Low Temperature High Activity of M (M = Ce, Fe, $\mathrm{Co}, \mathrm{Ni}$ ) Doped $\mathrm{M}-\mathrm{Mn} / \mathrm{TiO}_{2}$ Catalysts for $\mathrm{NH}_{3}$-SCR and in Situ DRIFTS for Investigating the Reaction Mechanism. Applied Surface Science, 515, Article ID: 146014. https://doi.org/10.1016/j.apsusc.2020.146014

[11] Wang, X., Wu, S., Zou, W., et al. (2016) Fe- Mn/ $\mathrm{Al}_{2} \mathrm{O}_{3}$ Catalysts for Low Temperature Selective Catalytic Reduction of $\mathrm{NO}$ with $\mathrm{NH}_{3}$. Chinese Journal of Catalysis, 37, 1314-1323. https://doi.org/10.1016/S1872-2067(15)61115-9

[12] Zhu, L. (2018) Study on the Performance and Mechanism of Low Temperature SCR Catalyst Denitrification with Transition Metal Oxides. Southeast University, Nanjing.

[13] Qiao, N.L., Yang, Y.X., Liu, Q.L., et al. (2018) Influence of Carrier Physicochemical Properties on the Denitrification Performance of $\mathrm{NH}_{3}$-SCR with Manganese Cerium Catalysts. Journal of Fuel Chemistry, 46, 733-742.

[14] Fang, D., Xie, J., Hu, H., et al. (2015) Identification of $\mathrm{MnO}_{x}$ Species and $\mathrm{Mn} \mathrm{Va-}$ lence States in $\mathrm{MnO}_{x} / \mathrm{TiO}_{2}$ Catalysts for Low Temperature SCR. Chemical Engineering Journal, 271, 23-30. https://doi.org/10.1016/j.cej.2015.02.072

[15] Tang, X., Li, Y., Huang, X., et al. (2006) $\mathrm{MnOx}-\mathrm{CeO}_{2}$ Mixed Oxide Catalysts for Complete Oxidation of Formaldehyde: Effect of Preparation Method and Calcination Temperature. Applied Catalysis B: Environmental, 62, 265-273. https://doi.org/10.1016/j.apcatb.2005.08.004

[16] Wang, Z., Shen, G., Li, J., et al. (2013) Catalytic Removal of Benzene over $\mathrm{CeO}_{2}-\mathrm{MnO}_{x}$ Composite Oxides Prepared by Hydrothermal Method. Applied Catalysis B Environmental, s138-s139, 253-259.

https://doi.org/10.1016/j.apcatb.2013.02.030

[17] Chen, L., Yao, X., Cao, J., et al. (2019) Effect of $\mathrm{Ti}^{4+}$ and $\mathrm{Sn}^{4+}$ Co-Incorporation on the Catalytic Performance of $\mathrm{CeO}_{2}-\mathrm{MnO}$ Catalyst for Low Temperature $\mathrm{NH}_{3}-\mathrm{SCR}$. Applied Surface Science, 476, 283-292. https://doi.org/10.1016/j.apsusc.2019.01.095

[18] Zhang, L., Zou, W., Ma, K., et al. (2015) Sulfated Temperature Effects on the Catalytic Activity of $\mathrm{CeO}_{2}$ in $\mathrm{NH}_{3}$-Selective Catalytic Reduction Conditions. The Journal of Physical Chemistry C, 119, 1155-1163. https://doi.org/10.1021/jp511282c

[19] Boningari, T., Ettireddy, P., Somogyvari, A., et al. (2015) Influence of Elevated Surface Texture Hydrated Titania on Ce-Doped $\mathrm{Mn} / \mathrm{TiO}_{2}$ Catalysts for the Low-Temperature SCR of $\mathrm{NO}_{x}$ under Oxygen-Rich conditions. Journal of Catalysis, 325, 145-155. https://doi.org/10.1016/j.jcat.2015.03.002

[20] Geng, Y., Chen, X., Yang, S., et al. (2017) Promotional Effects of Ti on a $\mathrm{CeO}_{2}-\mathrm{MoO}_{3}$ Catalyst for the Selective Catalytic Reduction of $\mathrm{NO}_{x}$ with $\mathrm{NH}_{3}$. ACS Applied Materials \& Interfaces, 9, 16951-16958. https://doi.org/10.1021/acsami.6b05380

[21] Kwon, D., et al. (2015) Influence of Tungsten on the Activity of a Mn/Ce/W/Ti Catalyst for the Selective Catalytic Reduction of $\mathrm{NO}$ with $\mathrm{NH}_{3}$ at Low Temperatures. Applied Catalysis A. General, 497, 160-166. https://doi.org/10.1016/j.apcata.2015.01.013

[22] Ma, H.Q., Tan, X. and Zhu, H.M. (2003) XPS Study of $\mathrm{La}_{(1-x)} \mathrm{Ce}_{x} \mathrm{FeO}_{3}$ Chalcocite High-Conversion Catalysts. Chinese Journal of Rare Earths, No. 4, 445-448.

[23] Yang, J.M. and Su, M. (1992) Structure and Bond Properties of $\mathrm{Laga}_{(1-x)} \mathrm{Fe}_{x} \mathrm{O}_{3}$. Chinese Journal of Rare Earths, No. 3. 
[24] Yu, Y.L., Zhang, R.F., Liu, S.T., et al. (1992) XPS Study of $\operatorname{LaMn}_{(1-x)} \operatorname{Co}_{x} \mathrm{O}_{(3-\lambda)}$ Catalysts. Chinese Journal of Rare Earths, No. 2, 134-137.

[25] Wang, J.S., Zhou, M.L., Zhang, J.X., et al. (2000) High-Temperature XPS Study of Carbonized $\mathrm{La}_{2} \mathrm{O}_{3}-\mathrm{Mo}$ Cathode Materials. Journal of Materials Science and Engineering, 29, 225-227.

[26] Gnanakumar, E., Naik, M., Manikandan, M., et al. (2014) Gopinath, Role of Nanointerfaces in $\mathrm{Cu}$ - and $\mathrm{Cu}$ plus Au-Based Near-Ambient-Temperature CO Oxidation Catalysts. ChemCatChem, 6, 3116-3124. https://doi.org/10.1002/cctc.201402581

[27] Zhao, K., Han, W., Lu, G.X., et al. (2016) Promotion of Redox and Stability Features of Doped Ce-W-Ti for $\mathrm{NH}_{3}$-SCR Reaction over a Wide Temperature Range. Applied Surface Science, 379, 316-322. https://doi.org/10.1016/j.apsusc.2016.04.090

[28] Xu, H., Xi, F., Shuang, L., et al. (2017) Promotional Effects of Titanium Additive on the Surface Properties, Active Sites and Catalytic Activity of $\mathrm{W} / \mathrm{CeZrO}_{x}$ Monolithic Catalyst for the Selective Catalytic Reduction of $\mathrm{NO}_{x}$ with $\mathrm{NH}_{3}$. Applied Surface Science, 419, 697-707. https://doi.org/10.1016/j.apsusc.2017.05.055

[29] Chang, L.H., Sasirekha, N., Chen, Y.W., et al. (2006) Preferential Oxidation of CO in $\mathrm{H}_{2}$ Stream over $\mathrm{Au} / \mathrm{MnO}_{2}-\mathrm{CeO}_{2}$ Catalysts. Industrial \& Engineering Chemistry Research, 45, 4927-4935. https://doi.org/10.1021/ie0514408

[30] Fan, J., Wu, X.D., Wu, X., et al. (2008) Thermal Ageing of Pt on Low-Surface-Area $\mathrm{CeO}_{2}-\mathrm{ZrO}_{2}-\mathrm{La}_{2} \mathrm{O}_{3}$ Mixed Oxides: Effect on the OSC Performance. Applied Catalysis B Environmental, 81, 38-48. https://doi.org/10.1016/j.apcatb.2007.11.022

[31] Gao, Y., Luan, T., Zhang, S., et al. (2019) Comprehensive Comparison between Nanocatalysts of $\mathrm{Mn}-\mathrm{Co} / \mathrm{TiO}_{2}$ and $\mathrm{Mn}-\mathrm{Fe} / \mathrm{TiO}_{2}$ for NO Catalytic Conversion: An Insight from Nanostructure, Performance, Kinetics, and Thermodynamics. Catalysts, 9, 175. https://doi.org/10.3390/catal9020175

[32] Gao, F., Tang, X., Yi, H., et al. (2017) In-Situ DRIFTS for the Mechanistic Studies of NO Oxidation over $\alpha-\mathrm{MnO}_{2}, \beta-\mathrm{MnO}_{2}$ and $\gamma-\mathrm{MnO}_{2}$ Catalysts. Chemical Engineering Journal, 322, 525-537. https://doi.org/10.1016/j.cej.2017.04.006

[33] Kapteijn, F., Singoredjo, L., Andreini, A., et al. (1994) Activity and Selectivity of Pure Manganese Oxides in the Selective Catalytic Reduction of Nitric Oxide with a Mmonia. Applied Catalysis B: Environmental, 3, 173-189.

https://doi.org/10.1016/0926-3373(93)E0034-9

[34] Luo, S., Zhou, W., Xie, A., et al. (2016) Effect of $\mathrm{MnO}_{2}$ Polymorphs Structure on the Selective Catalytic Reduction of $\mathrm{NO}_{x}$ with $\mathrm{NH}_{3}$ over $\mathrm{TiO}_{2}$-Palygorskite. Chemical Engineering, 286, 291-299. https://doi.org/10.1016/j.cej.2015.10.079

[35] Huang, J., Huang, H., Jiang, H., et al. (2018) The Promotional Role of Nd on $\mathrm{Mn} / \mathrm{TiO}_{2}$ Catalyst for the Low-Temperature $\mathrm{NH}_{3}-\mathrm{SCR}$ of $\mathrm{NO}_{x}$. Catalysis Today, 332, 49-58. https://doi.org/10.1016/j.cattod.2018.07.031

[36] Sun, P., Huang, S., Guo, R., et al. (2018) The Enhanced SCR Performance and $\mathrm{SO}_{2}$ Resistance of $\mathrm{Mn} / \mathrm{TiO}_{2}$ Catalyst by the Modification with Nb: A Mechanistic Study. Applied Surface Science, 447, 479-488. https://doi.org/10.1016/j.apsusc.2018.03.245

[37] Xu, Q., Su, R., Cao, L., et al. (2017) Facile Preparation of High-Performance Fe-Doped Ce-Mn/TiO ${ }_{2}$ Catalysts for the Low-Temperature Selective Catalytic Reduction of $\mathrm{NO}_{x}$ with $\mathrm{NH}_{3}$. RSC Advances, 7, 48785-48792.

https://doi.org/10.1039/C7RA07854D

[38] Li, Q., Gu, H., Li, P., et al. (2014) In Situ IR Studies of Selective Catalytic Reduction of $\mathrm{NO}$ with $\mathrm{NH}_{3}$ on Ce-Ti Amorphous Oxides. Chinese Journal of Catalysis, 35, 1289-1298. https://doi.org/10.1016/S1872-2067(14)60154-6 
[39] Liu, H., Fan, Z., Sun, C., et al. (2019) Improved Activity and Significant $\mathrm{SO}_{2}$ Tolerance of Samarium Modified $\mathrm{CeO}_{2}-\mathrm{TiO}_{2}$ Catalyst for NO Selective Catalytic Reduction with $\mathrm{NH}_{3}$. Applied Catalysis B: Environmental, 244, 671-683. https://doi.org/10.1016/j.apcatb.2018.12.001

[40] Yao, X., Zhao, R., Chen, L., et al. (2017) Selective Catalytic Reduction of $\mathrm{NO}_{x}$ by $\mathrm{NH}_{3}$ over $\mathrm{CeO}_{2}$ Supported on $\mathrm{TiO}_{2}$ : Comparison of Anatase, Brookite, and Rutile. Applied Catalysis B: Environmental, 208, 82-93. https://doi.org/10.1016/j.apcatb.2017.02.060

[41] Sun, J., Lu, Y., Zhang, L., et al. (2017) Comparative Study of Different Doped Metal Cations on the Reduction, Acidity, and Activity of $\mathrm{Fe}_{9} \mathrm{M}_{1} \mathrm{O}_{x}\left(\mathrm{M}=\mathrm{Ti}^{4+}, \mathrm{Ce}^{4+/ 3+}, \mathrm{Al}^{3+}\right)$ Catalysts for $\mathrm{NH}_{3}$-SCR Reaction. Industrial \& Engineering Chemistry Research, 56, 12101-12110. https://doi.org/10.1021/acs.iecr.7b03080

[42] Liu, Y., Gu, T., Weng, X., et al. (2012) DRIFT Studies on the Selectivity Promotion Mechanism of Ca-Modified Ce- $\mathrm{Mn} / \mathrm{TiO}_{2}$ Catalysts for Low-Temperature NO Reduction with $\mathrm{NH}_{3}$. The Journal of Physical Chemistry C, 116, 16582-16592. https://doi.org/10.1021/jp304390e

[43] Liao, Y.J., Zhang, Y.P., Yu, Y.X., et al. (2016) In Situ Infrared Study of the Mechanism of Low-Temperature Selective Catalytic $\mathrm{NO}_{x}$ Reduction by $\mathrm{MnO}_{x} / \mathrm{WO}_{3} / \mathrm{TiO}_{2}$. Journal of Chemical Engineering, 67, 5033-5037.

[44] Topsoe, N.Y. (1994) Mechanism of the Selective Catalytic Reduction of Nitric Oxide by A Mmonia Elucidated by in Situ On-Line Fourier Transform Infrared Spectroscopy. Science, 265, 1217-1219. https://doi.org/10.1126/science.265.5176.1217

[45] Chen, L., et al. (2010) DRIFT Study on Cerium-Tungsten/Titania Catalyst for Selective Catalytic Reduction of $\mathrm{NO}_{x}$ with $\mathrm{NH}_{3}$. Environmental Science \& Technology, 44, 9590-9596. https://doi.org/10.1021/es102692b

[46] Peña, D., Uphade, B., Reddy, E., et al. (2004) Identification of Surface Species on Titania-Supported Manganese, Chromium, and Copper Oxide Low-Temperature SCR Catalysts. The Journal of Physical Chemistry B, 108, 9927-9936. https://doi.org/10.1021/jp0313122

[47] Borfecchia, E., et al. (2015) Revisiting the Nature of $\mathrm{Cu}$ Sites in the Activated Cu-SSZ-13 Catalyst for SCR Reaction. Chemical Science, 6, 548-563. https://doi.org/10.1039/C4SC02907K

[48] Yao, X., Chen, L., Cao, J., et al. (2019) Enhancing the deNO Performance of $\mathrm{MnO} / \mathrm{CeO}_{2}-\mathrm{ZrO}_{2}$ Nanorod Catalyst for Low-Temperature $\mathrm{NH}_{3}-\mathrm{SCR}$ by $\mathrm{TiO}_{2}$ Modification. Chemical Engineering Journal, 369, 46-56.

https://doi.org/10.1016/j.cej.2019.03.052

[49] Sun, C., Liu, H., Chen, W., et al. (2018) Insights into the Sm/Zr Co-Doping Effects on $\mathrm{N}_{2}$ Selectivity and $\mathrm{SO}_{2}$ Resistance of a $\mathrm{MnO}_{x}-\mathrm{TiO}_{2}$ Catalyst for the $\mathrm{NH}_{3}-\mathrm{SCR}$ Reaction. Chemical Engineering, 347, 27-40. https://doi.org/10.1016/j.cej.2018.04.029

[50] Li, L., Wu, Y., Hou, X., et al. (2019) Investigation of Two-Phase Intergrowth and Coexistence in Mn-Ce-Ti-O Catalysts for the Selective Catalytic Reduction of NO with $\mathrm{NH}_{3}$ : Structure-Activity Relationship and Reaction Mechanism, Industrial \& Engineering Chemistry Research, 58, 849-862. https://doi.org/10.1021/acs.iecr.8b05066

[51] Song, L., Zhang, R., Zang, S., et al. (2017) Activity of Selective Catalytic Reduction of $\mathrm{NO}$ over $\mathrm{V}_{2} \mathrm{O}_{5} / \mathrm{TiO}_{2}$ Catalysts Preferentially Exposed Anatase 001 and 101 Facets. Catalysis Letters, 147, 934-945. https://doi.org/10.1007/s10562-017-1989-5

[52] Li, L., Tan, W., Wei, X., et al. (2018) Mo Doping as an Effective Strategy to Boost 
Low Temperature $\mathrm{NH}_{3}$-SCR Performance of $\mathrm{CeO}_{2} / \mathrm{TiO}_{2}$ Catalysts. Catalysis Communications, 114, 10-14. https://doi.org/10.1016/j.catcom.2018.05.015

[53] Bendrjch, M., Scheuer, A., Hayes, R., et al. (2018) Unified Mechanistic Model for Standard SCR, Fast SCR, and $\mathrm{NO}_{2}$ SCR over a Copper Chabazite Catalyst. Applied Catalysis B: Environmental, 222, 76-87. https://doi.org/10.1016/j.apcatb.2017.09.069

[54] Sun, D., Liu, Q., Liu, Z., et al. (2009) Adsorption and Oxidation of $\mathrm{NH}_{3}$ over $\mathrm{V}_{2} \mathrm{O}_{5} / \mathrm{AC}$ Surface. Applied Catalysis B Environmental, 92, 462-467. https://doi.org/10.1016/j.apcatb.2009.09.005

[55] Gianguido, R. and Angeles, L. (2004) An FT-IR Study of the Adsorption and Oxidation of N-Containing Compounds over $\mathrm{Fe}_{2} \mathrm{O}_{3} / \mathrm{Al}_{2} \mathrm{O}_{3}$ SCR Catalysts. Journal of Molecular Catalysis A Chemical, No. 1, 215. https://doi.org/10.1016/j.molcata.2004.01.016

[56] Shan, Y., Shi, X., He, G., et al. (2018) Effects of $\mathrm{NO}_{2}$ Addition on the $\mathrm{NH}_{3}-\mathrm{SCR}$ over Small-Pore Cu-SSZ-13 Zeolites with Varying Cu Loading. The Journal of Physical Chemistry C, 122, 25948-25953. https://doi.org/10.1021/acs.jpcc.8b05930

[57] Li, L., Zhang, F., Guan, N., et al. (2007) Selective Catalytic Reduction of NO by Propane in Excess Oxygen over IrCu-ZSM-5 Catalyst. Catalysis Communications, 8, 583-588. https://doi.org/10.1016/j.catcom.2006.08.013

[58] Mihaylov, M., Ivanova, E., Aleksandrov, H., et al. (2015) FTIR and Density Functional Study of NO Interaction with Reduced Ceria: Identification of $\mathrm{N}_{3}$ and $\mathrm{NO}_{2}$ as New Intermediates in NO Conversion. Applied Catalysis B: Environmental, s176-s177, 107-119. https://doi.org/10.1016/j.apcatb.2015.03.054

[59] Mu, J., Li, X., Sun, W., et al. (2018) An Inductive Effect Boosting Catalytic Performance of Advanced Fei- $\mathrm{xV}_{x} \mathrm{O}_{6}$ Catalysts in Low-Temperature $\mathrm{NH}_{3}$-SCR: An Insight into the Structure, Interaction, and Mechanisms. ACS Catalysis, 8, 6760-6774. https://doi.org/10.1021/acscatal.8b01196

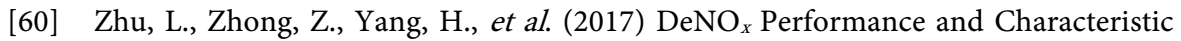
Study for Transition Metals Doped Iron Based Catalysts. Korean Journal of Chemical Engineering, 34, 1229-1237. https://doi.org/10.1007/s11814-016-0369-y 